\title{
The RNA-Binding Protein hnRNP K Mediates the Effect of BDNF on Dendritic mRNA Metabolism and Regulates Synaptic NMDA Receptors in Hippocampal Neurons
}

\author{
Graciano Leal, ${ }^{1}$ Diogo Comprido, ${ }^{1}$ DPasqualino de Luca, ${ }^{1}$ DEduardo Morais, ${ }^{1}$ Luís Rodrigues, ${ }^{1}$ \\ (1) Miranda Mele, ${ }^{1}$ - Ana R. Santos, ${ }^{1}$ - Rui O. Costa, ${ }^{1,2}$ - Maria Joana Pinto, ${ }^{1}$ (D) Sudarshan Patil, ${ }^{3}$ Birgitte \\ Berentsen, ${ }^{3}$ Pedro Afonso, ${ }^{1}$ Laura Carreto, ${ }^{4}{ }^{\circledR}$ Ka Wan Li, ${ }^{5}$ (D) Paulo Pinheiro, ${ }^{1,2}$ (D) Ramiro D. Almeida, ${ }^{1,2,4}$ \\ (D) Manuel A. S. Santos, ${ }^{4}$ Clive R. Bramham, ${ }^{3}$ and ${ }^{1}$ Carlos B. Duarte ${ }^{1,6}$
}

\section{DOI:http://dx.doi.org/10.1523/ENEURO.0268-17.2017}

${ }^{1}$ CNC-Center for Neuroscience and Cell Biology, University of Coimbra, 3004-504 Coimbra, Portugal, ${ }^{2}$ Institute for Interdisciplinary Research, University of Coimbra, 3030-789 Coimbra, Portugal, ${ }^{3}$ Department of Biomedicine and KG Jebsen Centre for Neuropsychiatric Disorders, University of Bergen, 5020 Bergen, Norway, ${ }^{4}$ Department of Medical Sciences and Institute of Biomedicine - iBiMED, University of Aveiro, 3810-193 Aveiro, Portugal, ${ }^{5}$ Center for Neurogenomics and Cognitive Research, Amsterdam Neuroscience, Vrije Universiteit, 1081 Amsterdam, The Netherlands, and ${ }^{6}$ Department of Life Sciences, University of Coimbra, 3000-456 Coimbra, Portugal

\begin{abstract}
Brain-derived neurotrophic factor (BDNF) is an important mediator of long-term synaptic potentiation (LTP) in the hippocampus. The local effects of BDNF depend on the activation of translation activity, which requires the delivery of transcripts to the synapse. In this work, we found that neuronal activity regulates the dendritic localization of the RNA-binding protein heterogeneous nuclear ribonucleoprotein $\mathrm{K}$ (hnRNP K) in cultured rat hippocampal neurons by stimulating BDNF-Trk signaling. Microarray experiments identified a large number of transcripts that are coimmunoprecipitated with hnRNP K, and about $60 \%$ of these transcripts are dissociated from the protein upon stimulation of rat hippocampal neurons with BDNF. In vivo studies also showed a role for TrkB signaling in the dissociation of transcripts from hnRNP K upon high-frequency stimulation (HFS) of medial perforant path-granule cell synapses of male rat dentate gyrus (DG). Furthermore, treatment of rat hippocampal synaptoneurosomes with BDNF decreased the coimmunoprecipitation of hnRNP $\mathrm{K}$ with mRNAs coding for glutamate receptor subunits, $\mathrm{Ca}^{2+}$ - and calmodulin-dependent protein kinase $\| \beta(\mathrm{CaMKII} \beta)$ and BDNF. Downregulation of hnRNP K impaired the BDNF-induced enhancement of NMDA receptor (NMDAR)-mediated mEPSC, and similar results were obtained upon inhibition of protein synthesis with cycloheximide. The results demonstrate
\end{abstract}

\section{Significance Statement}

Brain-derived neurotrophic factor (BDNF) is an important mediator of long-term synaptic potentiation (LTP) in the hippocampus, which is thought to underlie learning and memory formation. In this work we report the role of heterogeneous nuclear ribonucleoprotein $\mathrm{K}(\mathrm{hnRNP} \mathrm{K})$ as a novel mediator of the effects of BDNF on RNA metabolism in the dendritic compartment of hippocampal neurons. We found that at excitatory synapses BDNF reduces the interaction of hnRNP $\mathrm{K}$ with transcripts coding for synaptic proteins, including glutamate receptor subunits. This is likely to play an important role in synaptic plasticity mechanisms since hnRNP $\mathrm{K}$ was found to mediate the BDNF-induced enhancement of the activity of synaptic NMDA receptors (NMDARs), an effect that is dependent on protein synthesis. 
that BDNF regulates specific populations of hnRNP-associated mRNAs in neuronal dendrites and suggests an important role of hnRNP K in BDNF-dependent forms of synaptic plasticity.

Key words: BDNF; local translation; long-term synaptic potentiation; neurotrophins; NMDA receptors; RNA transport

\section{Introduction}

The neurotrophin brain-derived neurotrophic factor (BDNF) plays an important role on long-term synaptic potentiation (LTP) induced by high-frequency stimulation (HFS) of hippocampal Schaffer collateral-CA1 synapses (Korte et al., 1995, 1996; Kang et al., 1997; Minichiello et al., 1999) and at medial perforant path-granule cell synapses of the dentate gyrus (DG; Panja et al., 2014). Activation of BDNF-TrkB signaling also has a facilitatory effect on CA1 synapses, through stimulation of the protein synthesis machinery (Kang and Schuman, 1996; Schratt et al., 2004; Takei et al., 2004; Leal et al., 2014a; Panja and Bramham, 2014), and translation activity is required for the induction and consolidation of LTP following infusion of BDNF into the DG of anesthetized rats (Messaoudi et al., 2007; Panja et al., 2014). The BDNF-induced synthesis of proteins at the synapse relies on the local availability of the translation machinery (Steward and Levy, 1982), and on the presence of transcripts that are transported by motor proteins which travel along the microtubule tracks present in dendrites (Kanai et al., 2004; Santos et al., 2010; Leal et al., 2014a). The transport of RNAs along dendrites is made in large structures, the RNA granules, where the transcripts interact with specific proteins that stabilize them (Kanai et al., 2004; Elvira et al., 2006; Kosik, 2016). Studies performed in cultured hippocampal neurons showed that BDNF induces the dissociation of P-bodies, a class of RNA granules that may participate in the translational control of dendritically localized mRNAs, which may allow translation activity

Received August 1, 2017; accepted November 9, 2017; First published December 1, 2017

The authors declare no competing financial interests.

Author contributions: G.L., D.C., A.R.S., M.A.S., C.R.B., and C.B.D. designed research; G.L., D.C., P.d.L., E.M., L.R., M.M., R.O.C., and M.J.P. performed research; G.L., D.C., P.d.L., E.M., L.R., A.R.S., S.P., B.B., P.A., L.C., K.W.L., P.P., R.D.A., M.A.S.S., C.R.B., and C.B.D. analyzed data; G.L., C.R.B., and C.B.D. wrote the paper.

This work was supported by grants from the European Regional Development Fund (ERDF), through the Centro 2020 Regional Operational Programme (project CENTRO-01-0145-FEDER-000008:BrainHealth 2020), COMPETE 2020 - Operational Programme for Competitiveness and Internationalisation and Portuguese national funds via FCT - Fundação para a Ciência e a Tecnologia, I.P. (projects POCI-01-0145-FEDER-007440, PTDC/SAU-NEU/ 104297/2008 (to C.B.D.), PTDC/BEX-BCM/2121/2014 (to M.A.S.S.), UID/NEU/ 04539/2013, UID/BIM/4501/2013, SFRH/BPD/115546/2016 (to M.M.) and SFRH/BPD/84593/2012 (to R.O.C.)), GenomePT, Liga Portuguesa Contra a Epilepsia, The Research Council of Norway (Grants 204861 and 199355, to C.R.B.), and the Norwegian Financial Mechanism (Grant EMP128, to C.R.B.).

Correspondence should be addressed to Carlos B. Duarte, Center for Neuroscience and Cell Biology, Faculty of Medicine (Polo I), University of Coimbra, Rua Larga, 3004-504 Coimbra, Portugal. E-mail: cbduarte@ci.uc.pt. DOI:http://dx.doi.org/10.1523/ENEURO.0268-17.2017

Copyright (C) 2017 Leal et al.

This is an open-access article distributed under the terms of the Creative Commons Attribution 4.0 International license, which permits unrestricted use, distribution and reproduction in any medium provided that the original work is properly attributed.
(Zeitelhofer et al., 2008). However, the identity of the extracellular signals and the downstream mechanisms that regulate RNA metabolism in dendrites are poorly understood.

The RNA-binding protein heterogeneous nuclear ribonucleoprotein K (hnRNP K) was identified as a component of RNA transport granules in neurons (Elvira et al., 2006), and was detected in synaptoneurosomal fractions (Liao et al., 2007) as well at the postsynaptic densities in hippocampal neurons (Proepper et al., 2011; Folci et al., 2014). hnRNP $K$ has a modular structure with three $K$ homology $(\mathrm{KH})$ domains that interact with RNA and ss$\mathrm{DNA}$, and a $\mathrm{K}$ interactive region $(\mathrm{KI})$, which recruits a wide variety of factors, including kinases and regulators of splicing, mRNA stability and translation (Bomsztyk et al., 2004; Geuens et al., 2016). Given the presence of multiple domains for interaction with other molecules, it was proposed that hnRNP $\mathrm{K}$ may act as a docking platform to integrate signaling cascades by promoting the cross-talk between kinases and molecules involved in nucleic acid metabolism (Bomsztyk et al., 2004). At the postsynaptic density of hippocampal neurons hnRNP $\mathrm{K}$ interacts with Abelson-interacting protein 1 (Abi 1), a protein that plays an important role in the regulation of cytoskeleton reorganization and synaptic maturation (Courtney et al., 2000). Accordingly, hnRNP K was recently found to regulate the dendritic spine density in cultured hippocampal neurons (Folci et al., 2014). However, the role played by hnRNP $\mathrm{K}$ in the regulation of translation activity at the synapse remains to be characterized.

In this work we report a previously undescribed role of hnRNP $K$ as a mediator of the effects of BDNF in RNA metabolism in the dendritic compartment of hippocampal neurons. We found that neuronal activity induces the punctate accumulation of hnRNP $\mathrm{K}$ in dendrites by a mechanism dependent of BDNF. At the synapse, BDNF reduces the interaction of hnRNP $\mathrm{K}$ with transcripts coding for synaptic proteins, including glutamate receptor subunits. This may be relevant for synaptic plasticity mechanisms since hnRNP $\mathrm{K}$ was found to play an important role in BDNF-induced enhancement of the activity of synaptic NMDA receptors (NMDARs).

\section{Materials and Methods}

\section{Hippocampal cultures}

High-density hippocampal cultures were prepared from the hippocampi of embryonic day E18-E19 Wistar rat embryos, after treatment with trypsin $(0.06 \% ; 15$-min incubation at $37^{\circ} \mathrm{C}$; Gibco, Life Technologies) and DNase I $(5.36 \mathrm{mg} / \mathrm{ml})$ in $\mathrm{Ca}^{2+}$ - and $\mathrm{Mg}^{2+}$-free HBSS $(5.36 \mathrm{mM} \mathrm{KCl}$, $0.44 \mathrm{mM} \mathrm{KH}_{2} \mathrm{PO}_{4}, 137 \mathrm{mM} \mathrm{NaCl}, 4.16 \mathrm{mM} \mathrm{NaHCO}_{3}, 0.34$ $\mathrm{mM} \mathrm{Na} \mathrm{HPO}_{4} \cdot 2 \mathrm{H}_{2} \mathrm{O}, 5 \mathrm{mM}$ glucose, $1 \mathrm{mM}$ sodium pyruvate, $10 \mathrm{mM}$ HEPES, and $0.001 \%$ phenol red). The hippocampi were then washed with HBSS containing $10 \%$ 
fetal bovine serum (Gibco, Life Technologies), to stop trypsin activity, and transferred to Neurobasal medium (Gibco, Life Technologies) supplemented with SM1 supplement (1:50 dilution, STEMCELL Technologies), $25 \mu \mathrm{M}$ glutamate, $0.5 \mathrm{mM}$ glutamine, and $0.12 \mathrm{mg} / \mathrm{ml}$ gentamycin (Gibco, Life Technologies). The cells were dissociated in this solution and then plated in six-well plates $\left(90 \times 10^{3}\right.$ cells $\left./ \mathrm{cm}^{2}\right)$ coated with poly-D-lysine $(0.1 \mathrm{mg} / \mathrm{ml})$ for biochemical purposes (Western blotting and RNA coimmunoprecipitation), or on poly-D-lysine-coated coverslips $\left(80 \times 10^{3} \mathrm{cells} / \mathrm{cm}^{2}\right)$ for the analysis of NMDAR-mediated miniature EPSCs (mEPSCs). Cultures were maintained in a humidified incubator of $5 \% \mathrm{CO}_{2} / 95 \%$ air at $37^{\circ} \mathrm{C}$ for 14-17 $\mathrm{d}$ and then stimulated with $50 \mathrm{ng} / \mathrm{ml}$ BDNF (Peprotech) for the indicated periods of time.

Low-density hippocampal cultures were prepared as previously described (Kaech and Banker, 2006). Briefly, hippocampi were dissected from E18 rat embryos, and the cells were dissociated using trypsin $(0.02 \%)$ before plating in neuronal plating medium (MEM supplemented with $10 \%$ horse serum, $0.6 \%$ glucose, and $1 \mathrm{mM}$ pyruvic acid), at a final density of $1.43 \times 10^{4}$ cells $/ \mathrm{cm}^{2}$ on polyD-lysine-coated glass coverslips. After 2-4 h, coverslips were flipped over an astroglial feeder layer in Neurobasal medium (Invitrogen) supplemented with SM1 supplement (1:50 dilution, STEMCELL Technologies), $25 \mu \mathrm{M}$ glutamate, $0.5 \mathrm{mM}$ glutamine, and $0.12 \mathrm{mg} / \mathrm{ml}$ gentamycin (Gibco, Life Technologies). The neurons grew face down over the feeder layer but were kept separate from the glia by wax dots on the neuronal side of the coverslips. To prevent overgrowth of glial cells, neuron cultures were treated with $5 \mu \mathrm{M}$ cytosine arabinoside (Sigma-Aldrich) after 3 days in vitro (DIV). Cultures were maintained in a humidified incubator with $5 \% \mathrm{CO}_{2} / 95 \%$ air, at $37^{\circ} \mathrm{C}$, for up to two weeks, feeding the cells once per week. At DIV14-DIV15, neurons were stimulated for $30 \mathrm{~min}$ with $100 \mathrm{ng} / \mathrm{ml}$ BDNF (Peprotech) or with $50 \mu \mathrm{M}$ bicuculline (Tocris), $2.5 \mathrm{mM} 4-\mathrm{AP}$ (Tocris), and $10 \mu \mathrm{M}$ glycine (SigmaAldrich) to stimulate glutamate release and to increase synaptic activity. Where indicated, cells were pretreated for 30 min with the Trk receptor inhibitor SHN722 (1 $\mu \mathrm{M}$; Martin et al., 2011; Gomes et al., 2012) or with the scavenger of extracellular ligands of TrkB receptors TrkB-Fc (1 $\mu \mathrm{g} / \mathrm{ml}$; R\&D Systems) before stimulation with $100 \mathrm{ng} / \mathrm{ml}$ BDNF (Peprotech) or with the cocktail solution containing bicuculline (50 $\mu \mathrm{M}$ bicuculline, $2.5 \mathrm{mM} 4-\mathrm{AP}$, and $10 \mu \mathrm{M}$ glycine), respectively. Experiments were performed in a basal saline solution (132 mM NaCl, $4 \mathrm{mM} \mathrm{KCl}, 1.4 \mathrm{mM}$ $\mathrm{MgCl}_{2}, 2.5 \mathrm{mM} \mathrm{CaCl}_{2}, 6 \mathrm{mM}$ glucose, and $10 \mathrm{mM}$ HEPES at a final pH 7.4). Cells were then processed for immunocytochemistry.

\section{Immunocytochemistry}

Hippocampal neurons were fixed in $4 \%$ sucrose/paraformaldehyde (in PBS) for $15 \mathrm{~min}$ at room temperature and permeabilized with $0.3 \%$ Triton X-100 in PBS. Neurons were then incubated with $10 \%$ BSA in PBS, for 30 min at $37^{\circ} \mathrm{C}$, to block nonspecific staining, and incubated overnight at $4{ }^{\circ} \mathrm{C}$ with the primary antibodies diluted in $3 \%$ BSA in PBS. The following primary antibodies and dilu- tions were used: anti-hnRNP K (sc-28380, 1:200; Santa Cruz Biotechnology), anti-GFP (598, 1:500, MBL International), and anti-MAP2 (ab5392, 1:10.000, Abcam). The cells were washed six times with PBS for 2 min and incubated with Alexa Fluor 568 (1:500, Invitrogen), Alexa Fluor 488 (1:500; Invitrogen), and aminomethylcoumarin (AMCA) (1:200; Jackson ImmunoResearch) conjugated secondary antibodies, for $45 \mathrm{~min}$ at $37^{\circ} \mathrm{C}$. After washing the cells six times with PBS for 2 min, the coverslips were mounted with a fluorescence mounting medium (DAKO).

\section{Microscopy and quantitative fluorescence analysis}

Imaging was performed on a Zeiss Observer Z.1 microscope using a $63 \times 1.4 \mathrm{NA}$ oil objective. Images were quantified using the ImageJ image analysis software. For quantitation, sets of cells were cultured and stained simultaneously, and imaged using identical settings. The protein signals were analyzed after setting the thresholds, and the recognizable clusters under those conditions were included in the analysis. Regions of interest (ROI) were drawn in secondary dendrites with no segmentation performed. The integrated intensity, area, and number of hnRNP K particles was determined only within the ROI and represented per dendritic area (as assessed by MAP2 staining). All analyses were performed blind to the experimental condition.

\section{Preparation of hippocampal culture extracts}

Hippocampal cultures with 15 DIV $\left(90 \times 10^{3} \mathrm{cells} / \mathrm{cm}^{2}\right)$ were washed twice with ice-cold PBS, and once more with PBS buffer supplemented with $1 \mathrm{mM}$ dithiothreitol (DTT) and a cocktail of protease inhibitors $[0.1 \mathrm{mM}$ phenylmethylsulfonyl fluoride (PMSF) and CLAP $(1 \mu \mathrm{g} / \mathrm{ml}$ chymostatin, $1 \mu \mathrm{g} / \mathrm{ml}$ leupeptin, $1 \mu \mathrm{g} / \mathrm{ml}$ antipain, and 1 $\mu \mathrm{g} / \mathrm{ml}$ pepstatin; Sigma)]. The cells were then lysed with RIPA $(150 \mathrm{mM} \mathrm{NaCl}, 50 \mathrm{mM}$ Tris- $\mathrm{HCl}, \mathrm{pH} 7.4,5 \mathrm{mM}$ EGTA, $1 \%$ Triton, $0.5 \% \mathrm{DOC}$, and $0.1 \%$ SDS at a final $\mathrm{pH}$ 7.5) supplemented with $50 \mathrm{mM}$ sodium fluoride (NaF), 1.5 $\mathrm{mM}$ sodium ortovanadate $\left(\mathrm{Na}_{3} \mathrm{VO}_{4}\right)$, and the cocktail of protease inhibitors. After sonication and centrifugation at $16,100 \times g$ for $10 \mathrm{~min}$ at $4^{\circ} \mathrm{C}$, protein in the supernatants was quantified using the bicinchoninic acid (BCA) assay kit (Pierce). Samples were then denaturated with $2 \times$ concentrated denaturating buffer (125 mM Tris, pH 6.8, 100 $\mathrm{mM}$ glycine, 4\% SDS, $200 \mathrm{mM}$ DTT, 40\% glycerol, $3 \mathrm{mM}$ $\mathrm{Na}_{3} \mathrm{VO}_{4}$, and $0.01 \%$ bromophenol blue) for $5 \mathrm{~min}$ at $95^{\circ} \mathrm{C}$, and proteins of interest were analyzed by Western blotting. Alternatively, extracts were performed in a lysis buffer supplemented with $50 \mathrm{U} / \mathrm{ml}$ of RNase inhibitor (SUPERaseln, Ambion Applied Biosystems) and samples processed for RNA coimmunoprecipitation experiments.

\section{Synaptoneurosome preparation}

Synaptoneurosomes were prepared as previously described with slight modifications (Yin et al., 2002). Briefly, six to eight hippocampi were dissected from adult male and female Wistar rats, and the tissue was minced with scissors and homogenized with a glass homogenizer in a buffer containing $0.32 \mathrm{M}$ sucrose, $10 \mathrm{mM}$ HEPES-Tris, $\mathrm{pH}$ 7.4, and $0.1 \mathrm{mM}$ EGTA. After centrifugation for $3 \mathrm{~min}$ at $1000 \times g$, the supernatant was collected and passed 
initially through nylon membranes (150 and $50 \mu \mathrm{m}$, VWR) and finally through an $8-\mu \mathrm{m}$ pore size filter (Millipore). The flow-through was centrifuged for $15 \mathrm{~min}$ at 10,000 $\times \mathrm{g}$, and the pellet was resuspended in incubation buffer (8 $\mathrm{mM} \mathrm{KCl}, 3 \mathrm{mM} \mathrm{CaCl}_{2}, 5 \mathrm{mM} \mathrm{Na}_{2} \mathrm{HPO}_{4}, 2 \mathrm{mM} \mathrm{MgCl}_{2}, 33$ $\mathrm{mM}$ Tris, $72 \mathrm{mM} \mathrm{NaCl}$, and $100 \mathrm{mM}$ sucrose). All the procedure was done at $4^{\circ} \mathrm{C}$. Synaptoneurosomes were incubated or not with $50 \mathrm{ng} / \mathrm{ml}$ BDNF (Peprotech) or 20 $\mathrm{ng} / \mathrm{ml}$ PDGF (Peprotech) for $10 \mathrm{~min}$ at $30^{\circ} \mathrm{C}$ and were then centrifuged at maximum speed, in a Minispin microcentrifuge for $30 \mathrm{~s}$. For each time point considered a control experiment was also performed in the absence of the neurotrophic factors. The pellet was resuspended in RIPA buffer supplemented as indicated for the hippocampal culture extract preparation, followed by sonication and protein quantification using the BCA method. Proteins of interest were analyzed by Western blotting. For RNA coimmunoprecipitation experiments, RIPA buffer was supplemented with $50 \mathrm{U} / \mathrm{ml}$ of the RNase inhibitor SUPERase.In (Ambion Applied Biosystems).

\section{Lactate dehydrogenase (LDH) activity}

Synaptoneurosomes were centrifuged at top speed for $30 \mathrm{~s}$ to separate the pellet containing the synaptic fraction and the "extracellular" fraction, and the pellet was lysed in $15 \mathrm{mM}$ Tris- $\mathrm{HCl}, \mathrm{pH} 7.1$ ( $t=0 \mathrm{~min})$. Alternatively, synaptoneurosomes were maintained in incubation buffer for 45 $\min$ at $30^{\circ} \mathrm{C}$ and processed in the same way. The concentration of protein in the synaptoneurosomes extract was quantified using the Bio-Rad method and $25 \mu \mathrm{g}$ of total protein were used to assay LDH activity. LDH activity was also measured in the extracellular fraction. The activity of the enzyme was measured at $340 \mathrm{~nm}$ in $100 \mathrm{mM}$ Tris- $\mathrm{HCl}, \mathrm{pH} 7.1$, supplemented with $0.3 \mathrm{mM} \mathrm{NADH}$ (Sigma) and $10 \mathrm{mM}$ pyruvate (Sigma). The absorbance of $\mathrm{NAD}^{+}$was measured at $37^{\circ} \mathrm{C}$ during $5 \mathrm{~min}$, with intervals of $50 \mathrm{~s}$. A negative control was performed in the absence of pyruvate. LDH activity in each sample was calculated by subtracting the slope of the negative control. LDH activity for each fraction was calculated as the ratio to the total LDH activity.

\section{Western blotting}

Samples were resolved by SDS-PAGE in $10 \%$ polyacrylamide gels. For Western blot analysis, proteins were transferred onto a PVDF membrane (Millipore) by electroblotting $\left(40 \mathrm{~V}\right.$, overnight at $\left.4^{\circ} \mathrm{C}\right)$. The membranes were blocked for $1 \mathrm{~h}$ with skin milk and $0.1 \%$ Tween 20 in TBS (20 mM Tris, $137 \mathrm{mM} \mathrm{NaCl}$, pH 7.6; TBS-T), and probed with the primary antibody overnight at $4^{\circ} \mathrm{C}$. Following several washes with TBS-T, the membranes were incubated with an alkaline phosphatase-conjugated IgG secondary antibody (anti-mouse or anti-rabbit, depending on the primary antibody host-species) for $1 \mathrm{~h}$ at room temperature. The membranes were then washed again and immunostaining was visualized by the enhanced chemifluorescence method (ECF) on a Storm $860 \mathrm{Gel}$ and Blot Imaging System (GE Health Care). For the analysis of total extracts from DG homogenates, horseradish peroxidase (HRP)-conjugated secondary antibodies were used and immunostaining was developed using chemilumines- cence reagents (ECL, GE Healthcare). In this case the blots were scanned using Gel DOC EQ (Bio-Rad). Antibodies used in Western blotting experiments were the following: anti-hnRNP K (sc-28380, 1:1000; Santa Cruz Biotechnology), anti-p-Akt S304 (1:1000; Cell Signaling), anti-pERK1/2 Thr202/Tyr204 (1:500; Promega), anti-HR3 (1:1000; Millipore), anti-PSD-95 (1:2000; Cell Signaling Technology), anti-vesicular GABA transporter (VGAT; 1:2000; Synaptic Systems), anti-GFAP (1:1000; Oncogene), and anti-synaptophysin (1:1000; Abcam). When indicated, anti- $\beta$-tubulin (T7816, 1:30,000; Sigma-Aldrich), anti-GAPDH (sc32233, 1:5000; Santa Cruz Biotechnology), or anti- $\beta$-actin (A5441, 1:5000; Sigma-Aldrich) antibodies were used as loading control.

\section{Immunoprecipitation and mRNA extraction}

Antibody-immobilized beads were prepared by incubating $6 \mu \mathrm{g}$ of hnRNP K or mouse IgG antibodies with 100 $\mu l$ of Protein G PLUS-Agarose beads (Santa Cruz Biotechnology), overnight at $4^{\circ} \mathrm{C}$ in $\mathrm{NT}_{2} 2 \times$ buffer containing $100 \mathrm{mM}$ Tris- $\mathrm{HCl}, 300 \mathrm{mM} \mathrm{NaCl}, 2 \mathrm{mM} \mathrm{MgCl}, 0.1 \%$ IGEPAL, pH 7.4, and supplemented with $1 \mathrm{mM} \mathrm{DTT}$ and a cocktail of protease inhibitors [0.1 mM PMSF and CLAP (Sigma)]. The immobilized antibodies were incubated with $1 \mathrm{mg}$ of protein for $1 \mathrm{~h}$ at $4^{\circ} \mathrm{C}$, and the beads were washed four times $(2-m i n$ centrifugations, $2000 \times g)$ with $\mathrm{NT}_{2} 1 \mathrm{x}$ buffer at $4^{\circ} \mathrm{C}$. The supernatant was discarded and the final pellet, containing the immunoprecipitated hnRNP bound to the antibody-immobilized beads, was used for further analysis. For RNA coimmuprecipitations, $\mathrm{NT}_{2}$ buffer was supplemented with $50 \mathrm{U} / \mathrm{ml}$ of RNase inhibitor (SUPERaseln, Ambion Applied Biosystems), and the TRIzol Reagent (Invitrogen) was immediately added to the pellet and the RNA extracted according to manufacturer's instructions.

For the RNA coimmunoprecipitations performed using total extracts from DG homogenates, the same procedure was performed with minor changes: $50 \mu \mathrm{l}$ of Protein G Sepharose 4 Fast Flow (GE Health Care) beads and 500 $\mu \mathrm{g}$ of protein were used for the immunoprecipitations and the $\mathrm{NT}_{2}$ buffer was supplemented with cOmplete, Mini EDTA-free protease inhibitors cocktail (Roche) and 40 $\mathrm{U} / \mathrm{ml}$ RiboLockRNase inhibitor (Thermo Fischer).

For the microarray analysis, RNA coimmunoprecipitations were performed with the following modifications: cellular extracts were prepared using the RiboCluster Profiler RIP-Assay kit (MBL International Corporation) supplemented with $50 \mathrm{mM} \mathrm{NaF}, 1: 200$ Protease Inhibitor Cocktail Set III (Calbiochem, Merck), 1 mM DTT, and $80 \mathrm{U}$ of RNase inhibitor (SUPERaseln, Ambion Applied Biosystems). Immunoprecipitated mRNAs were isolated using the RiboCluster Profiler RIP-Assay kit (MBL International Corporation).

In all cases, parallel experiments were performed in which the nonspecific binding of RNAs to Protein G PLUS-Agarose beads (or Protein G Sepharose 4 Fast Flow beads) was determined and the RNAs were resuspended in the same volume of RNase-free water. The RNA concentration was determined using NanoDrop 
(Thermo Scientific), and samples were stored at $-80^{\circ} \mathrm{C}$ until further use.

\section{Gene expression microarray}

The RNA isolated from the hnRNP/lgG immunoprecipitates was subjected to microarray analysis using the OneColor Microarray-Based Gene Expression Protocol v6.0. The Low Input Quick Amp Labeling (Agilent Technologies) protocol was used for the preparation and labeling of the biological targets, hybridization, washing, scanning, and data analysis, as recommended by the manufacturer. The Whole Rat Genome Microarray kit $(4 \times 44 \mathrm{~K}$, Agilent Technologies) was used and analyzed with a high-resolution microarray scanner (G2565AA, Agilent Technologies). hnRNP K-bound mRNAs were identified by setting a cutoff value of the fold variation between the hnRNP $K$ and IgG samples. For this identification, we have used a cutoff value of 5 , i.e., only transcripts showing at least 5 -fold variation in their abundance in the hnRNP K immunoprecipitates when compared with the IgG controls were considered specifically associated with the RNP. Transcripts regulated by BDNF were identified after subtracting the results obtained in extracts incubated with mouse IgG, and then by comparing the hnRNP K immunoprecipitates microarray data obtained for control and BDNF-treated hippocampal neurons. Calculation of the fold variation in RNA-hnRNP K interaction induced by BDNF showed significant changes $(p<0.05)$ for 9509 transcripts.

The list of all mRNAs that coimmunoprecipitated with hnRNP K $(16,015)$ and those that were significantly regulated by BDNF (9509) are provided in Extended Data Tables 1-1, 1-5, respectively. The PANTHER classification system (Mi et al., 2013a) was used to evaluate functional categories present and enriched in the list of mRNAs that associate with hnRNP $\mathrm{K}$ and are regulated by BDNF. The Gene Ontology (GO) analysis included the most enriched biological processes associated with transcripts bound to hnRNP $\mathrm{K}$ and those that were regulated by BDNF. Only categories showing at least a 2-fold increase, when comparing the number of mRNAs obtained in each category with the expected number considering the size of our lists, were considered for analysis. Categories were then ordered according to the highest -log ( $p$ value).

\section{Reverse transcription and quantitative PCR (qPCR)}

For mRNA measurement, $500 \mathrm{ng}$ to $1 \mu \mathrm{g}$ of total RNA was reverse transcribed using a blend of oligo (dT) and random hexamer primers, and iScript Reverse Transcriptase (iScriptcDNA Synthesis kit, 170-8891; Bio-Rad). Primers for qRT-PCR were designed by Beacon Designer 7 software (Premier Biosoft International). The following considerations were taken: (1) GC content $~ 50 \%$; (2) annealing temperature (Ta) between $55 \pm 5^{\circ} \mathrm{C}$; (3) secondary structures and primer dimers were avoided; (4) primer length 18-24 bp; and (5) final product length 100$200 \mathrm{bp}$.

Primer sequences were as follows: Gria1 (GluA1), FWACTACATCCTCGCCAATCTG; REV-AGTCACTTGTCCTCCATTGC; Gria2 (GluA2), FW-TCTCTTCTAACAGCATACA; REV-AAACTGAACCATCCCTAC; Grin1 (GluN1), FW-CGGCTCTTGGAAGATACAG; REV-GAGTGAAGTGGTCGTTGG;
Camk2b (CaMKII $\beta$ ), FW-GCTATACGAGGATATTGG; REVTCTTGGTGTTAATGATCT; Hnrnpk (hnRNP K), FW-AACACTCAGACAACAATCA; REV-TCCTCCAATAAGAACAACTC; Hprt1 (Hprt), FW-CCTTGACTATAATGAGCACTTC; REVGCCACATCAACAGGACTC; Npas4 (NPAS4), FW-AATGGAGATATTCAGGCT; REV-TAGTTATTGGCAGTAATAGG; Ntrk2 (TrkB), FW-GATCTTCACCTACGGCAAGC; REV-TCG CCAAGTTCTGAAGGAGT; and Bdnf (BDNF), FW-TAACCTCGCTCATTCATTA; REV-TCAACTCTCATCCACCTT. An additional set of primers was used for mRNA measurements from DG total homogenates: bdnf (BDNF), FWTGGGACTCTGGAGAGCGTGAATGG; REV-CGGGACTTT CTCCAGGACTGTGAC.

qPCR was performed using SsoFast EvaGreen Supermix (172-5201; Bio-Rad). A total of $2 \mu$ l of $1: 5$ diluted CDNA (1:4 for microarray analysis) was used and the final concentration of each primer was $250 \mathrm{nM}$ in a $20 \mu \mathrm{l}$ final volume. The thermocycling reaction was initiated with activation of Taq DNA polymerase by heating at $95^{\circ} \mathrm{C}$ during $30 \mathrm{~s}$, followed by 45 cycles of a $10 \mathrm{~s}$ denaturation step at $95^{\circ} \mathrm{C}$, a 30 -s annealing step at the optimal primer temperature of annealing and a 30-s elongation step at $72^{\circ} \mathrm{C}$. The fluorescence was measured after the extension step by the iQ5 Multicolor Real-Time PCR Detection System (Bio-Rad). After the thermocycling reaction, the melting step was performed with slow heating, starting at $55^{\circ} \mathrm{C}$ and with a rate of $0.5^{\circ} \mathrm{C}$ per $10 \mathrm{~s}$, up to $95^{\circ} \mathrm{C}$, with continuous measurement of fluorescence allowing detection of nonspecific products. To analyze the mRNA coimmunoprecipitated with hnRNP $\mathrm{K}$ from DG total homogenates, the qRT-PCR was performed in a final volume of $8 \mu \mathrm{l}$ with $2 \times$ SYBR Green Master Mix (BioRad), and using a LightCycler 480 (Roche). The reaction was initiated with a preamplification step of $3 \mathrm{~min}$ at $95^{\circ} \mathrm{C}$, followed by 45 cycles of a 10 -s denaturation step at $95^{\circ} \mathrm{C}$, a 10 -s annealing step at the optimal primer temperature of annealing, a 10-s elongation step at $72^{\circ} \mathrm{C}$, and warming from $65^{\circ} \mathrm{C}$ to $95^{\circ} \mathrm{C}$ for the melting curve.

\section{qPCR data analysis}

The comparative threshold cycle (Ct) method was used to quantitate the relative gene expression across the experimental conditions. The $\mathrm{Ct}$ represents the detectable fluorescence signal above background resulting from the accumulation of amplified product, and is a proportional measure of the starting target sequence concentration. Ct was measured on the exponential phase and, for every run, Ct was set at the same fluorescence value. Data analysis of the log-transformed expression data were performed using GenEx (MultiD Analysis) software for realtime PCR expression profiling.

\section{Animals and presurgical treatment}

Animals used in the in vivo experiments were Sprague Dawley outbreed strain (M\&B A/S) weighing 250-300 g at the time of use. Animals were housed in a temperatureand light-controlled vivarium $\left(21 \pm 1^{\circ} \mathrm{C} ; 12 / 12 \mathrm{~h}\right.$ light/dark artificial circadian rhythm) and supplied with a high protein diet type MR1 (Special Diet Services) and water for at least one week before surgery. Animals were retrieved 
from the animal facility in a separate cage into the laboratory where they were anesthetized with Urethane $(250$ $\mathrm{mg} / \mathrm{ml} ; 1.4-1.8 \mathrm{mg} / \mathrm{kg}$ ) according to their individual weight. Urethane was administered via intraperitoneal injection. The first injection contained $1 / 3$ of the total dosage and after $5 \mathrm{~min}$ the animal was weighed for accurate measurements, and the final $2 / 3$ of the anesthetic was given.

\section{Stereotaxic surgery and electrode positioning}

Male Sprague Dawley rats were positioned in a stereotaxic frame (David Kopfs Instruments) with the upper incisor bar $2 \mathrm{~mm}$ below the interaural line (skull flat position), the ear bars placed at the side of the head in the natural jaw sockets and a nose-and-tooth bar supported by the upper jaw of the animal. If required, supplemental doses of urethane were given to maintain a surgical level of anesthesia. Rectal temperature was maintained at $36^{\circ} \mathrm{C}$ with a thermostatically controlled electric heating pad. A scalpel was used to make a $1.5-\mathrm{cm}$ longitudinal cut on the top of the animal's head. Four bulldog clamps (FST) were used to reflect the skin giving open access to the scalp. The surface of the scalp was kept dry and free from blood. Burr holes were drilled in the appropriate location for the insertion of the stimulating and recording electrodes. A sharp needle was used to incise the dura to facilitate the penetration of the electrodes. Two holes were drilled anterior to bregma in the frontal bone to attach the ground and reference electrodes. The stimulation electrodes were bipolar, concentric, stainless steel, and with a vertical tip separation of $500 \mu \mathrm{m}$ (SNEX 100; Rhodes Medical Instruments). The recording electrodes were Teflon-coated seven-strand stainless steel (or tungsten) wires (\#7955/ 7960 , A-M System Inc) of $\sim 8-10 \mathrm{~cm}$ in length. The ground and reference electrodes were Teflon-coated seven-strand stainless steel wires (\#7925/7935, A-M System Inc). Stereotaxic coordinates for the unilateral stimulation of the medial perforant path fibers in the angular bundle were as follows (in $\mathrm{mm}$, relative to bregma): 7.9 posterior and 4.2 lateral. Stereotaxic coordinates for recording in the hilar region of the DG were as follows (in $\mathrm{mm}$, relative to bregma): 3.9 posterior and 2.2 lateral. When positioned on the accurate coordinates, both stimulation and recording electrodes were gradually lowered down to their final position. The final depth for the stimulation and recording electrodes was 1.8-2.4 and $3.3 \mathrm{~mm}$ below dura, respectively.

\section{In vivo electrophysiology and intrahippocampal infusion}

After the correct positioning of the electrodes, the medial perforant path fibers in the angular bundle were unilaterally stimulated and the evoked field potentials (fEPSPs) recorded in the hilar region of the DG. After stabilization, baseline was recorded for $20 \mathrm{~min}$. Test pulses were applied at $0.033 \mathrm{~Hz}$ throughout the experiment except during the period of HFS. The intensity of the stimulus for test pulses and for HFS was set to the intensity that evoked $1 / 3$ of maximum population spike. The HFS paradigm to induce long-term potentiation (LTP) consisted of eight pulses of $400 \mathrm{~Hz}$, repeated four times at 10-s intervals. Three sessions of HFS were given at intervals of five minutes. Intrahippocampal infusions were made using a stainless steel cannula system (Plastics One) consisting of an outer guide tube (24 gauge) and an inner infusion tube (31 gauge). The guide cannula was beveled sharp at the tip to facilitate brain insertion. The recording electrode was attached to the guide cannula and cut so that the distance between the electrode and the tip of the inner infusion cannula was $0.8-0.9 \mathrm{~mm}$. The guide cannula-electrode assembly was slowly lowered until a positive-going field EPSP (fEPSP) of maximum slope was obtained in the dentate hilus. The infusion cannula was then inserted so that the tip protruded 300 $\mu \mathrm{m}$ below the end of the guide cannula. The infusion site was located $700 \mu \mathrm{m}$ above the hilar recording site (corresponding to deep CA1 stratum lacunosum-moleculare), and 300-400 $\mu \mathrm{m}$ above the medial perforant pathgranule cell synapses. The response was allowed to stabilize for $1 \mathrm{~h}$. After baseline recordings $(20 \mathrm{~min})$ the infusions were performed with a pump that ensures the gradual infusion of $1 \mu \mathrm{l} \mathrm{TrkB-Fc}(100 \mu \mathrm{g} / \mu \mathrm{l}, 688-\mathrm{TK})$ or IgG-FC (100 $\mu \mathrm{g} / \mu \mathrm{l}, 110-\mathrm{HG}$; R\&D Systems) over a 12.5min time period. HFS was performed $18 \mathrm{~min}$ after the infusion.

\section{Dissection and preparation of DG homogenates}

At the end of the electrophysiological recording, the rats were decapitated and the brain rapidly removed and transferred to a glass plate covered with ice-cold salinesoaked filter paper. The DG was dissected under ice-cold conditions. After the hippocampus has been removed and placed ventral side up, the DG was gently rolled out and cut along the fissure separating it from CA3. The fimbria was also cut away and blood vessels removed. The DG and the hippocampal CA1 and CA3 regions were then stored in microtubes, and were instantly frozen in a mixture of $96 \%$ methanol and dry ice. Samples were kept at $-80^{\circ} \mathrm{C}$ until further use. The dentate gyri were homogenized in $400 \mu$ lice-cold RIPA buffer $(150 \mathrm{mM} \mathrm{NaCl}, 50 \mathrm{mM}$ Tris- $\mathrm{HCl}, \mathrm{pH} 7.4,5 \mathrm{mM}$ EGTA, $1 \%$ Triton, $0.5 \% \mathrm{DOC}$, and $0.1 \%$ SDS at a final $\mathrm{pH} 7.5$ ) containing $50 \mathrm{mM} \mathrm{NaF}$ and supplemented with with cOmplete, Mini EDTA-free protease inhibitors cocktail (Roche), and $40 \mathrm{U} / \mathrm{ml}$ RiboLock RNase inhibitor (Thermo Fischer). A fraction of the homogenate sample was set aside for Western blot analysis and the remaining homogenate used for the RNA coimmunoprecipitation experiments.

\section{Field potential analysis}

The fEPSP was analyzed using the software Datawave Experimental Workbench (DataWave Systems). Between two points on the fEPSP, five points were randomly selected to calculate the steepness of the slope. Data files were coverted to ASCII format and further analyzed in the Microsoft Office Excel 2010 (Microsoft Corporation). fEPSP is presented as percentage change from baseline.

\section{hnRNP K knockdown in neuronal cultures}

\section{Constructs}

TRIP $\Delta$ U3-E1a-EGFP (pTRIP) lentiviral vectors (Sirven et al., 2001) were used to deliver double-stranded hairpin 
Table 1. Templates used for nontargeting (control) shRNA and hnRNP K

\begin{tabular}{|c|c|c|c|}
\hline sh-scramble & $\begin{array}{l}\text { Target sequence } \\
\text { none }\end{array}$ & $\begin{array}{l}\text { Sense oligo } \\
\text { GATCCCC } \\
\text { GATGAACGCTCTGGATGCG } \\
\text { TTCAAGAGA } \\
\text { CGCATCCAGAGCGTTCATC } \\
\text { TTTTGGAAA }\end{array}$ & $\begin{array}{l}\text { Anti-sense oligo } \\
\text { AGCTTTTCCAAAAA } \\
\text { GATGAACGCTCTGGATGCG } \\
\text { TCTCTTGAA } \\
\text { CGCATCCAGAGCGTTCATC } \\
\text { GGG }\end{array}$ \\
\hline sh-hnRNP K & $\begin{array}{l}\text { 1201-1219 } \\
\text { GUAACUAUUCCCAAAGAUU }\end{array}$ & $\begin{array}{l}\text { GATCCCC } \\
\text { GTAACTATTCCCAAAGATT } \\
\text { TTCAAGAGA } \\
\text { AATCTTTGGGAATAGTTAC } \\
\text { TTTITGGAAA }\end{array}$ & $\begin{array}{l}\text { AGCTTTTCCAAAAA } \\
\text { GTAACTATTCCCAAAGATT } \\
\text { TCTCTTGAA } \\
\text { AATCTTTGGGAATAGTTAC } \\
\text { GGG }\end{array}$ \\
\hline
\end{tabular}

RNA sequences (shRNA) for hnRNP $K$ knockdown in neuronal primary cultures. To obtain shRNA templates, the sense and antisense strands were designed to contain 19-22 nt duplex connected by a short loop-structure (5'TTCAAGAGA-3'), and flanked by 5'-Bglll and 3'-HindIII restriction site. The templates used were 5'-gatgaacgctctggatgcg-3' for the nontargeting (control) shRNA template and 5'-gtaactattcccaaagatt-3' for hnRNP K (Table 1).

After annealing, oligonucleotides were cloned into the Bglll and Hindlll digested pSuper (EcoRI) intermediate vector. Then, a fragment containing the $\mathrm{H} 1$ promoter and hairpin sequences were obtained from EcoRl-digested pSuper, and subcloned into the EcoRI site of the pTRIP lentiviral vector.

\section{Lentiviruses construction and transduction of neuronal cultures}

Lentiviruses were generated by triple calcium-phosphate transfection of pTRIPshRNA (coding also GFP), pCMV- $\Delta$ R8.91, and pMD (VSVG; which encode the VSVG envelope glycoprotein gene and the gag/pol/tat genes, respectively) into HEK293T cells. HEK293T cells were grown for $2 \mathrm{~d}$ in 10-cm Petri dishes until they reached $\sim 60 \%$ confluence. A solution of $\mathrm{CaCl}_{2}$ and DNA (Helper plasmids: $10 \mu \mathrm{g}$ pCMV- $\Delta$ R8.91, $6 \mu \mathrm{g}$ pMD.G(VSVG); plasmid with the specific constructs: $5 \mu \mathrm{g}$ pTrip -shRNA) was added drop-wise to a solution of $2 \times$ HEPES-buffered saline (HBS; $50 \mathrm{mM}$ HEPES, $280 \mathrm{mM} \mathrm{NaCl}$, and $1.5 \mathrm{mM}$ $\mathrm{Na}_{2} \mathrm{HPO}_{4}, \mathrm{pH}$ 7.0). The solution of calcium-DNA was dropwise added to $2 \times$ HBS and rested for $10 \mathrm{~min}$ to form the precipitates. The precipitates were then distributed evenly over the HEK293T cultures. The cells were allowed to incorporate the precipitates for $6 \mathrm{~h}$ and were further incubated for $\sim 60 \mathrm{~h}$ to express the plasmid content. During these periods cells were maintained at $37^{\circ} \mathrm{C}$, with saturating humidity and $5 \% \mathrm{CO}_{2} / 95 \%$ air. The supernatant containing viral particles was then collected and concentrated by centrifugation at $60,000 \times g$ for $2 \mathrm{~h}$ at $22^{\circ} \mathrm{C}$ (Pinto et al., 2016). Viral particles were resuspended in $0.1 \%$ BSA in PBS and stored at $-80^{\circ} \mathrm{C}$. Viral titer was calculated as previously described (Janas et al., 2006).

Neuronal cultures were transduced at DIV11 with a multiplicity of infection (MOI) equal to 5 , which represents $\sim 80 \%$ of neuronal infection. Coverslips with low-density hippocampal neuronal cultures growing over a layer of astroglia cells were transferred to sterile 12-multiwell plates where the cells were transduced for $6 \mathrm{~h}$ in $500 \mu \mathrm{l}$ of conditioned media. After that period, the coverslips were gently washed in sterile PBS and then transferred to the wells containing the astroglia cell layer. Neurons were allowed to express the shRNA for $3 \mathrm{~d}$. At 14 DIV, the neurons were processed for immunocytochemistry. The shRNA constructs used in Western blotting experiments were designed to carry a mCherry tag instead of GFP.

\section{Transfection of shRNA constructs}

Hippocampal cultures were transfected using the calcium phosphate coprecipitation method with constructs carrying shRNAs targeting hnRNP $\mathrm{K}$ or a scramble sequence. Briefly, hippocampal neurons were incubated with cultured-conditioned medium with $2 \mathrm{mM}$ kynurenic acid (Sigma) for $15 \mathrm{~min}$. Two $\mu \mathrm{g}$ of plasmid DNA was diluted in Tris-EDTA (TE), $\mathrm{pH} 7.3$, and mixed with $2.5 \mathrm{M}$ $\mathrm{CaCl}_{2}$. This DNA/TE/calcium mix was added to $10 \mathrm{mM}$ HBS solution $(270 \mathrm{mM} \mathrm{NaCl}, 10 \mathrm{mM} \mathrm{KCl}, 1.4 \mathrm{mM}$ $\mathrm{Na}_{2} \mathrm{HPO}_{4}, 11 \mathrm{mM}$ dextrose, and $42 \mathrm{mM}$ HEPES, $\mathrm{pH}$ 7.2). The precipitates were added drop-wise to each well and incubated for $1 \mathrm{~h} 30 \mathrm{~min}$ at $37^{\circ} \mathrm{C}$, in a humidified incubator with $95 \%$ air $/ 5 \% \mathrm{CO}_{2}$. The cells were then washed with acidic culture medium containing $2 \mathrm{mM}$ kynurenic acid and returned to the $95 \%$ air/5\% CO $\mathrm{CO}_{2}$ incubator for $20 \mathrm{~min}$ at $37^{\circ} \mathrm{C}$. Finally, the medium was replaced with the initial culture-conditioned medium, and the cells were further incubated in a $95 \%$ air $/ 5 \% \mathrm{CO}_{2}$ incubator for $72 \mathrm{~h}$ at $37^{\circ} \mathrm{C}$. Hippocampal neurons transfected with sh-scramble or shhnRNP $\mathrm{K}$ were stimulated or not with BDNF (50 ng/ml) during at least $30 \mathrm{~min}$ before recording the NMDARmediated mEPSCs.

\section{Analysis of NMDAR-mediated mEPSCs}

Cultured hippocampal neurons $\left(2.71 \times 10^{5}\right.$ cells/well) with pyramidal morphology (15-17 DIV), were whole-cell voltage-clamped to $-60 \mathrm{mV}$, at room temperature, in a $\mathrm{MgCl}_{2}$-free Tyrode's solution containing: $150 \mathrm{mM} \mathrm{NaCl}, 4$ $\mathrm{mM} \mathrm{KCl}, 10 \mathrm{mM}$ glucose, $10 \mathrm{mM}$ HEPES, and $2 \mathrm{mM}$ $\mathrm{CaCl}_{2}, \mathrm{pH} 7.35$ (310 mOsm). To record and isolate NMDAR-mediated mEPSCs, 6-cyano-7-nitroquinoxaline2,3-dione (CNQX; $10 \mu \mathrm{M}$; Tocris; AMPA/kainate receptor antagonist), bicuculline (10 $\mu \mathrm{M}$; Tocris; $\mathrm{GABA}_{\mathrm{A}}$ receptor antagonist), tetrodotoxin (TTX; 500 nM; Tocris; blocker of voltage gated $\mathrm{Na}^{+}$channels), and glycine (15 $\mu \mathrm{M}$; SigmaAldrich; coagonist of NMDARs) were added to the bath solution (Atasoy et al., 2008). The electrode solution had 
the following composition: $115 \mathrm{mM}$ Cs-MeSO, $20 \mathrm{mM}$ $\mathrm{CsCl}, 2.5 \mathrm{mM} \mathrm{MgCl}_{2}, 10 \mathrm{mM}$ HEPES, 0.6 mM EGTA, 4 $\mathrm{mM} \mathrm{Na} \mathrm{N}_{2}$-ATP, and 0.4 mM Na-GTP, pH 7.3 (300 mOsm; Sigma; Kessels et al., 2013). Where indicated, hippocampal neurons were preincubated with cycloheximide (CHX; $50 \mu \mathrm{g} / \mathrm{ml}$ ) or with vehicle (DMSO; 1:1000 dilution) for 15 min before recording the NMDAR-mediated mEPSC. When the effect of BDNF was tested, hippocampal neurons were preincubated with the neurotrophin $(50 \mathrm{ng} / \mathrm{ml})$ for at least $30 \mathrm{~min}$ before recording the NMDAR-mediated mEPSCs. Recording electrodes were made of borosilicate glass capillaries and pulled on a horizontal stage Sutter Instrument P-97 puller (resistances: 3-4 M $\Omega$ ). Recordings were made without series resistance compensation. Cells were held for a period of $5 \mathrm{~min}$ and the baseline for the analysis of NMDAR-mediated mEPSCs was manually determined as the average current level of silent episodes during a recording. Whole-cell recordings from hippocampal neurons were performed using an Axon CNS, Multiclamp 700B amplifier, an Axon Digidata $1550 \mathrm{~A}$ acquisition board, and pClamp software (version 10.5; Molecular Devices). Signals were filtered at $2.8 \mathrm{~Hz}$, sampled at $25 \mathrm{kHz}$ and the amplitude of NMDARmediated currents was analyzed offline with pClamp software (version 10.5; Molecular Devices).

\section{Statistical analysis}

Data are presented as mean \pm SEM of at least three different experiments, performed in independent preparations. Statistical analysis of the results was performed using one-way ANOVA analysis followed by the Dunnett or Bonferroni multiple comparison tests, as indicated in the figure captions. Where indicated, comparison between two experimental groups was performed using the Student's $t$-test.

\section{Results}

\section{Neuronal activity regulates the dendritic expression} of hnRNP $K$ through activation of TrkB receptors

Several transcripts are transported to dendrites on neuronal activation, including the mRNAs encoding for Arc (Link et al., 1995; Lyford et al., 1995; Steward et al., 1998; Steward and Worley, 2001), $\beta$-actin (Tiruchinapalli et al., 2003), CaMKII $\alpha$ (Thomas et al., 1994; Rook et al., 2000; Håvik et al., 2003), TrkB, and BDNF (Tongiorgi et al., 1997). To understand whether neuronal activity regulates hnRNP K protein levels in dendrites, we stimulated cultured hippocampal neurons (14-15 DIV) with a cocktail solution containing bicuculline to increase the excitatory activity of the neuronal network (Hardingham et al., 2002). The dendritic distribution of hnRNP $\mathrm{K}$ was evaluated by immunocytochemistry, through colocalization with the dendritic marker MAP2. hnRNP K exhibited a punctate distribution along dendrites, as expected for a component of neuronal mRNP involved in dendritic mRNA transport. Bicuculline treatment significantly increased the integrated intensity, as well as the area of hnRNP K puncta in dendrites (Fig. 1A,B). However, no alteration was observed in the total number of hnRNP K puncta (Fig. 1A,B).
Since BDNF is released in an activity-dependent manner (Edelmann et al., 2014), we hypothesized that the neurotrophin could play a role in bicuculline-induced dendritic accumulation of hnRNP K. To address this hypothesis, hippocampal neurons were stimulated with bicuculline in the presence of an extracellular scavenger of TrkB ligands, TrkB-Fc. Buffering of extracellular BDNF with TrkB-Fc abrogated the effect of neuronal activity on the dendritic distribution of hnRNP $\mathrm{K}$ without affecting the basal levels of the protein in the same compartment, suggesting an important role for BDNF in the activityinduced accumulation of hnRNP K in dendrites. Accordingly, stimulation of hippocampal neurons with BDNF also upregulated the intensity and area of dendritic hnRNP K puncta, and this effect was abrogated by the Trk receptor inhibitor SHN722 (Martin et al., 2011; Fig. 1C,D). Furthermore, no effect of BDNF was observed in the number of hnRNP $\mathrm{K}$ puncta (Fig. 1C,D), in accordance with the results obtained on bicuculline treatment. Together, these results show that BDNF plays an important role in the activity-dependent expression pattern of dendritic hnRNP $K$ protein. Since bicuculline stimulation was without effect on total hnRNP K protein levels, as determined by Western blotting (Extended Data Fig. 1-1), the activity-dependent alteration in the localization of the RNA-binding protein in hippocampal neurons is likely to result from its redistribution.

\section{Characterization of the hnRNP K-binding transcripts}

The presence of hnRNP $\mathrm{K}$ in dendrites suggests that this RNP plays a role in the delivery of transcripts away from the soma. Therefore, we characterized the transcripts that (directly or indirectly) interact with hnRNP K using a RNP immunoprecipitation (RIP) assay. hnRNP K was immunoprecipitated from cultured hippocampal neurons (DIV15) under control conditions, and the coimmunoprecipitated RNA fractions were subjected to whole-rat genome Agilent microarray analysis. Control experiments using a mouse IgG antibody showed no hnRNP K immunoprecipitation confirming the specificity of the method (not shown). The RNA transcripts that specifically coimmunoprecipitated with hnRNP $\mathrm{K}$ were identified by setting a cutoff value of 5 in the fold change of transcript coprecipitation when comparing hnRNP K and IgG samples. Thus, only transcripts showing at least 5 -fold variation, when their abundance in the hnRNP $\mathrm{K}$ immunoprecipitates was compared with the IgG controls, were considered specifically associated with the RNP.

The RNAs that coimmunoprecipitated with hnRNP K, a total of 16,015 transcripts (Extended Data Table 1-1), were analyzed using the PANTHER classification system that uses the GO algorithm (Mi et al., 2013a). Classification of these transcripts based on their role in biological processes showed that the most enriched categories were related with excitatory synapse plasticity (Table 2; Fig. 2A). The mRNAs coimmunoprecipitated with hnRNP $\mathrm{K}$ are involved in diverse processes such as glutamate receptor signaling, regulation of synapse structure and function, regulation of dendrite development, synapse assembly, postsynaptic signaling, and learning (Fig. 2A; Table 2; Extended Data Table 1-2). Accordingly, when the 
A

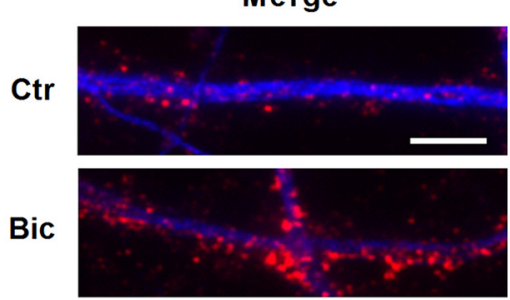

TrkB-Fc

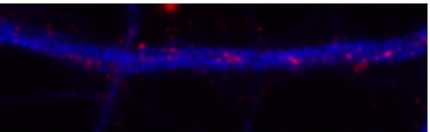

Bic

+ TrkB-Fc

B

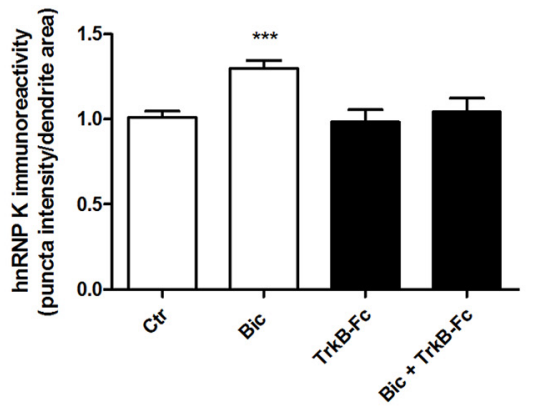

C

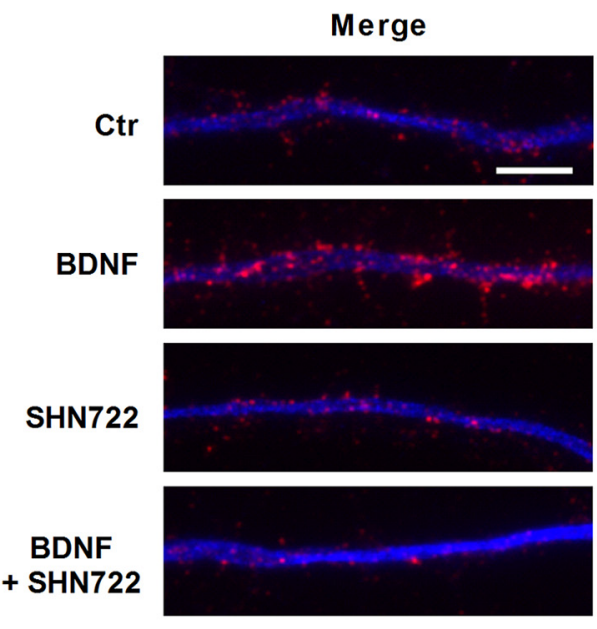

D

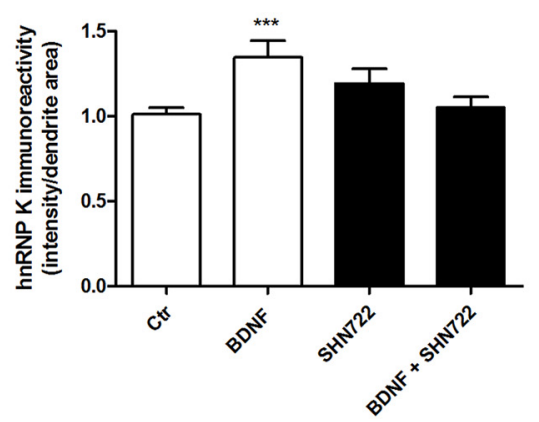

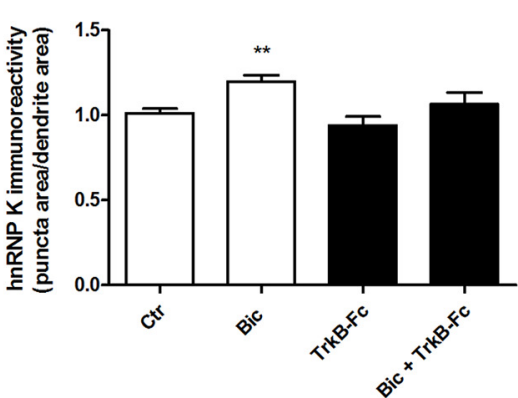

hnRNP K
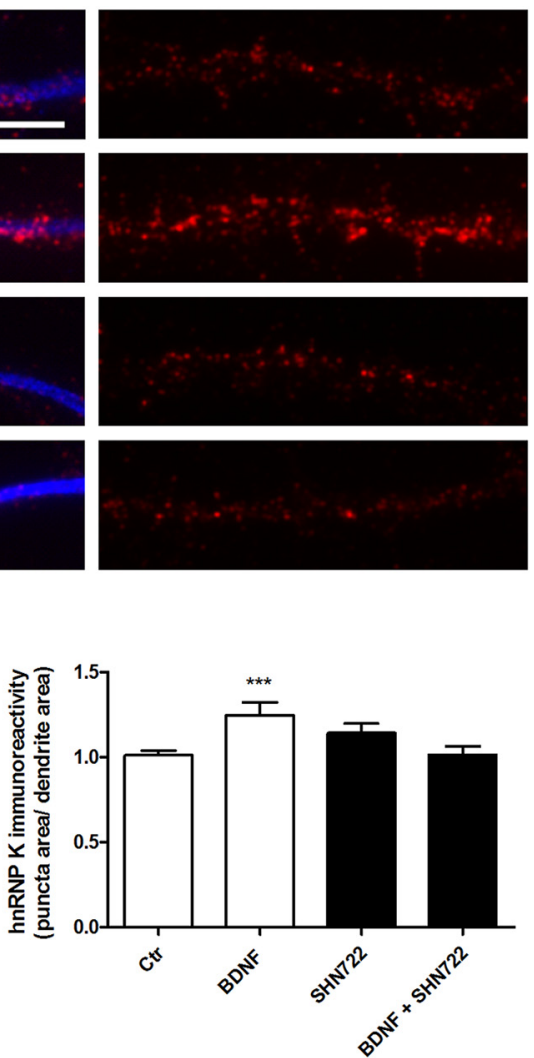

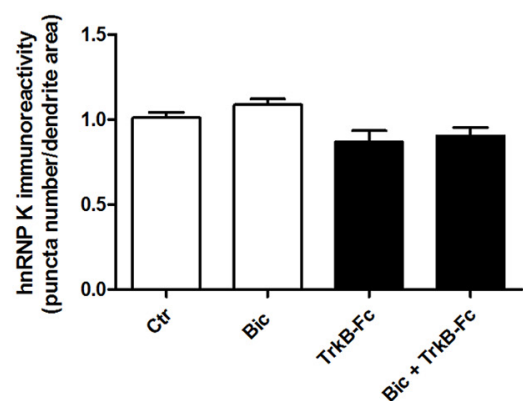

MAP2
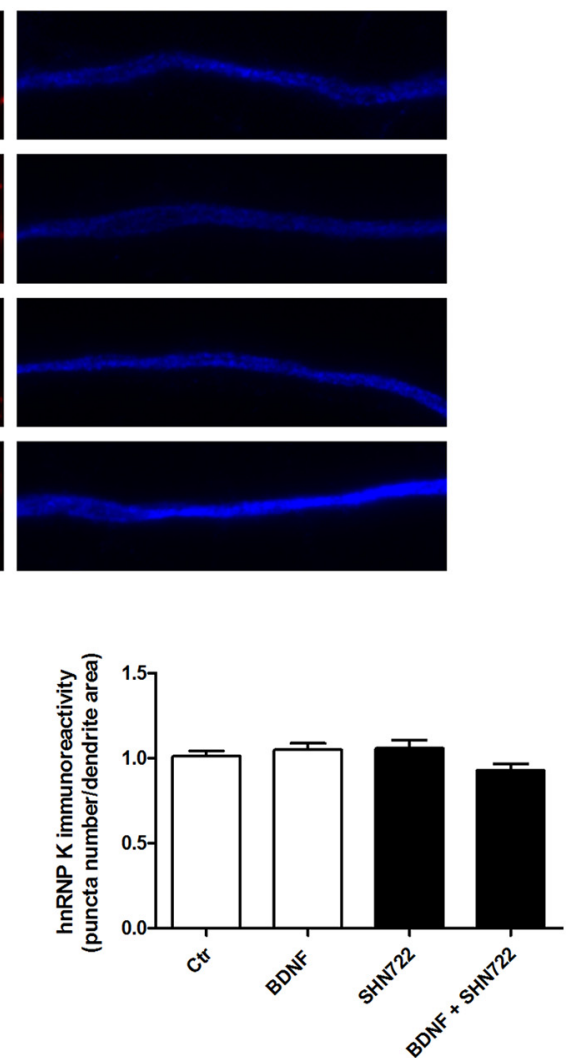

Figure 1. Activity-induced BDNF-dependent dendritic accumulation of hnRNP $\mathrm{K}$ in hippocampal neurons. $\boldsymbol{A}, \boldsymbol{B}$, Synaptic activity 


\section{continued}

induces the accumulation of hnRNP $\mathrm{K}$ in dendrites of hippocampal neurons. Cultured hippocampal neurons (14-15 DIV) were stimulated or not with bicuculline $(50 \mu \mathrm{M}), 4-\mathrm{AP}(2.5 \mathrm{mM})$, and glycine $(10 \mu \mathrm{M})$, for $30 \mathrm{~min}$. Where indicated, neurons were treated with the extracellular scavenger of TrkB ligands TrkB-Fc $(1 \mu \mathrm{g} / \mathrm{ml})$ for $30 \mathrm{~min}$ and were then stimulated or not with bicuculline in the presence of the scavenger. Cells were then fixed and immunostained for hnRNP K (red) and MAP2 (blue) (A). The integrated fluorescence intensity, area, and number of hnRNP K puncta in dendrites was analyzed using ImageJ software and represented per dendritic area $(\boldsymbol{B})$. Results are normalized to control and are the mean \pm SEM of 4-10 different experiments performed in independent preparations. Ctr, $n=108$ cells; Bic, $n=97$ cells; TrkB-Fc, $n=49$ cells; Bic + TrkB-Fc, $n=52$ cells. $\boldsymbol{C}, \boldsymbol{D}$, BDNF increases hnRNP $\mathrm{K}$ levels in neuronal dendrites. Cultured hippocampal neurons (14-15 DIV) were stimulated or not with BDNF (100 ng/ml) for $30 \mathrm{~min}$. Where indicated, neurons were preincubated with the Trk receptor inhibitor SHN722 for 30 min, and the inhibitor was also present during the period of incubation with the neurotrophin. Cells were then fixed and immunostained for hnRNP K (red) and MAP 2 (blue) (C). The integrated fluorescence intensity, area, and number of hnRNP K puncta in dendrites was analyzed using Image J software and represented per dendritic area $(\boldsymbol{D})$. Results are normalized to control and are the mean \pm SEM of 4-10 different experiments performed in independent preparations. Ctr, $n=108$ cells; BDNF, $n=53$ cells; SHN722, $n=41$ cells; BDNF + SHN722, $n=51$ cells. Statistical analysis was performed by one-way ANOVA, followed by the Bonferroni's multiple comparison test. $* * p<0.01 ; * * * p<$ 0.001 . Scale bars: $5 \mu \mathrm{m}$. Extended Data Figure 1-1 shows that neuronal activity does not change total hnRNP K protein levels in cultured hippocampal neurons.

coimmunoprecipitated transcripts were analyzed based on the cellular component, the identified mRNAs were found to be associated with postsynaptic membrane/ postsynaptic density/dendritic spines, further suggesting that hnRNP K plays an important regulatory role at the postsynaptic level (Extended Data Table 1-3). Interestingly, a significant fraction of the transcripts identified code for proteins of the presynaptic active zone and

Table 2. List of the most enriched biological processes associated with hnRNP K target mRNAs

\begin{tabular}{|c|c|c|c|c|c|c|}
\hline GO biological process & $\begin{array}{l}\text { Rattus novergicus } \\
\text { (reference list) }\end{array}$ & $\begin{array}{l}\text { Uploaded } \\
\text { list }\end{array}$ & (Expected) & (Over/under) & $\begin{array}{l}\text { fold } \\
\text { enrichment }\end{array}$ & ( $p$ value) \\
\hline Glutamate receptor signaling pathway & 44 & 39 & 17.26 & + & 2.26 & 3.81E-02 \\
\hline Amino acid transport & 90 & 76 & 35.31 & + & 2.15 & $1.46 \mathrm{E}-05$ \\
\hline Synapse assembly & 51 & 43 & 20.01 & + & 2.15 & 4.35E-02 \\
\hline Dendrite morphogenesis & 57 & 48 & 22.36 & + & 2.15 & $1.34 \mathrm{E}-02$ \\
\hline Dendrite development & 106 & 89 & 41.58 & + & 2.14 & 8.56E-07 \\
\hline $\begin{array}{l}\text { Regulation of neuronal } \\
\text { synaptic plasticity }\end{array}$ & 71 & 59 & 27.85 & + & 2.12 & $1.46 \mathrm{E}-03$ \\
\hline $\begin{array}{l}\text { Regulation of synaptic } \\
\text { plasticity }\end{array}$ & 181 & 148 & 71.00 & + & 2.08 & $6.28 \mathrm{E}-12$ \\
\hline Forebrain cell migration & 70 & 57 & 27.46 & + & 2.08 & 4.35E-03 \\
\hline $\begin{array}{l}\text { Regulation of dendrite } \\
\text { morphogenesis }\end{array}$ & 94 & 76 & 36.88 & + & 2.06 & 8.66E-05 \\
\hline $\begin{array}{l}\text { Telencephalon cell } \\
\text { migration }\end{array}$ & 67 & 54 & 26.28 & + & 2.05 & $1.14 \mathrm{E}-02$ \\
\hline $\begin{array}{l}\text { Positive regulation of } \\
\text { dendrite development }\end{array}$ & 91 & 73 & 35.70 & + & 2.04 & 2.24E-04 \\
\hline $\begin{array}{l}\text { Negative regulation of } \\
\text { synaptic transmission }\end{array}$ & 64 & 51 & 25.11 & + & 2.03 & 2.96E-02 \\
\hline Learning & 159 & 126 & 62.37 & + & 2.02 & 6.53E-09 \\
\hline $\begin{array}{l}\text { Regulation of synapse } \\
\text { structure or activity }\end{array}$ & 280 & 221 & 109.84 & + & 2.01 & $3.29 \mathrm{E}-17$ \\
\hline $\begin{array}{l}\text { Positive regulation of } \\
\text { synapse assembly }\end{array}$ & 66 & 52 & 25.89 & + & 2.01 & 3.27E-02 \\
\hline Synaptic vesicle cycle & 94 & 74 & 36.88 & + & 2.01 & 3.75E-04 \\
\hline $\begin{array}{l}\text { Regulation of postsynaptic } \\
\text { membrane potential }\end{array}$ & 65 & 51 & 25.50 & + & 2.00 & $4.48 \mathrm{E}-02$ \\
\hline Neurotransmitter secretion & 102 & 80 & 40.01 & + & 2.00 & $1.29 \mathrm{E}-04$ \\
\hline Signal release from synapse & 102 & 80 & 40.01 & + & 2.00 & 1.29E-04 \\
\hline Regulation of synapse assembly & 83 & 65 & 32.56 & + & 2.00 & 2.79E-03 \\
\hline Presynaptic process involved in & 106 & 83 & 41.58 & + & 2.00 & 7.57E-05 \\
\hline
\end{tabular}

More detailed information is provided in Extended Data Tables 1-1-1-8: Table 1-1, hnRNP K coimmunoprecipitated transcripts; Table 1-2, biological processes associated with mRNAs coimmunoprecipitated with hnRNP K as assessed by GO; Table 1-3, cellular components associated with mRNAs coimmunoprecipitated with hnRNP K as assessed by GO; Table 1-4, molecular functions associated with mRNAs coimmunoprecipitated with hnRNP K as assessed by GO; Table 1-5, hnRNP K coimmunoprecipitated transcripts regulated by BDNF; Table 1-6, biological processes associated with mRNAs coimmunoprecipitated with hnRNP $\mathrm{K}$ and regulated by BDNF as assessed by GO; 1-7, cellular components associated with mRNAs coimmunoprecipitated with hnRNP $\mathrm{K}$ and regulated by BDNF as assessed by GO; 1-8, molecular functions associated with mRNAs coimmunoprecipitated with hnRNP K and regulated by BDNF as assessed by GO. 
A

\section{Control}

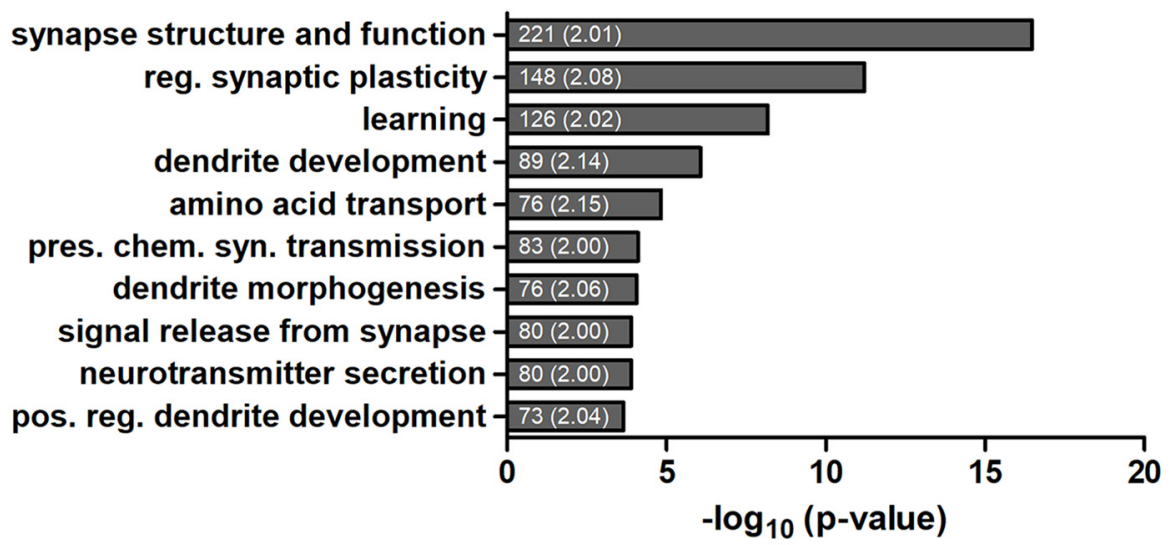

B

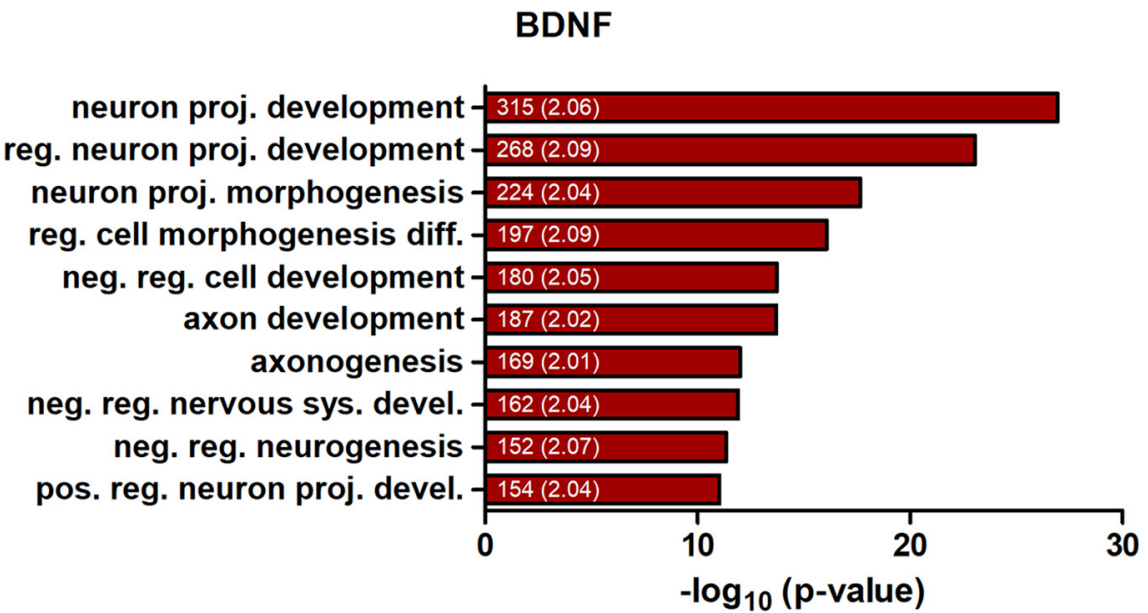

C

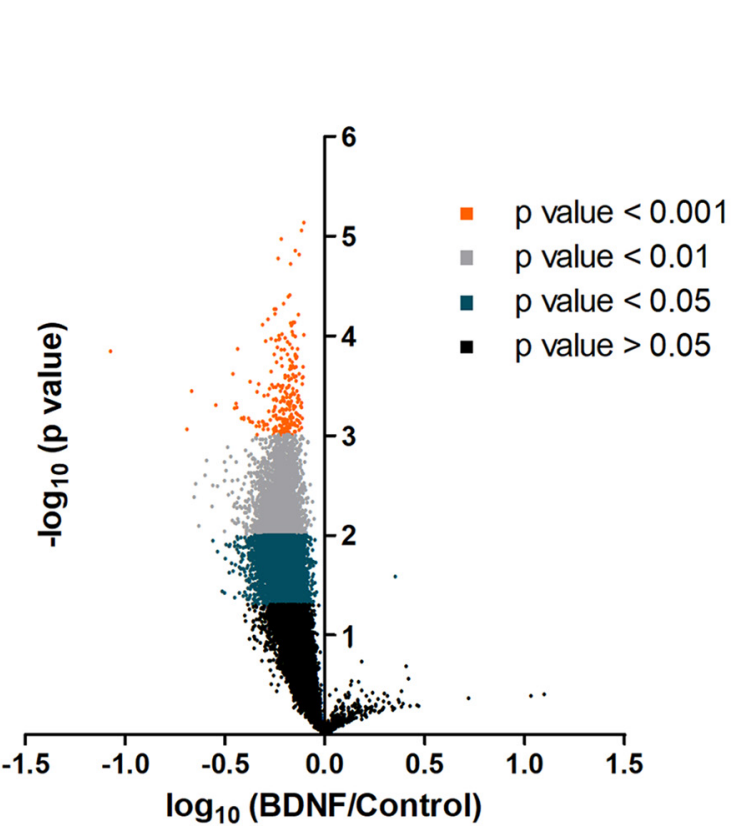

D

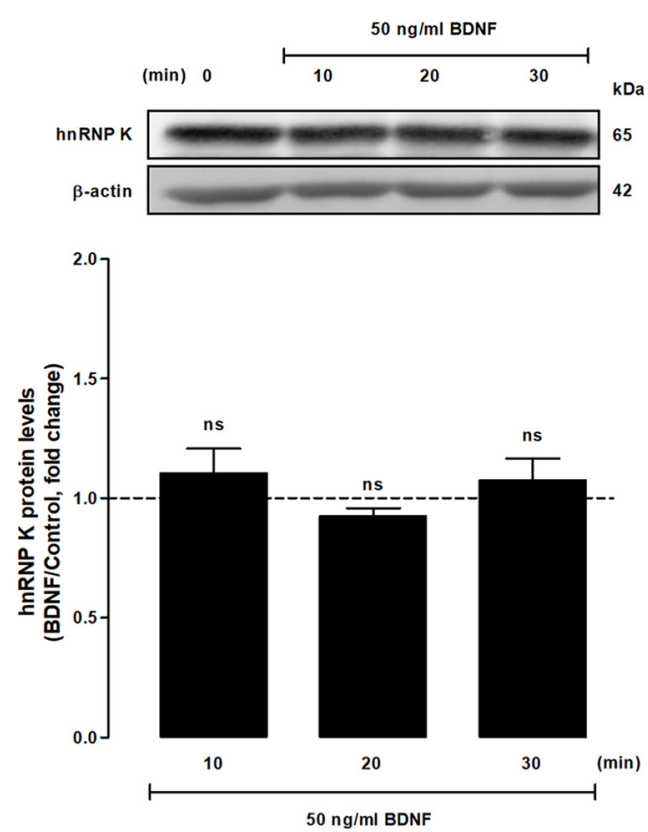

Figure 2. Stimulation of hippocampal neurons with BDNF decreases the interaction of hnRNP $\mathrm{K}$ with a large number of transcripts. $\boldsymbol{A}, \boldsymbol{B}$, List of the 10 most significantly enriched biological processes associated with mRNAs bound to hnRNP K $(\boldsymbol{A})$ and those that 


\section{continued}

were regulated by BDNF (50 $\mathrm{ng} / \mathrm{ml}$ for $10 \mathrm{~min}$ ) $(\boldsymbol{B})$, identified with the PANTHER classification system. Only categories showing at least a 2 -fold enrichment (considering the size of our lists) were analyzed and the 10 categories displaying the highest -log ${ }_{10}(p$ value) are shown. The number of transcripts belonging to each category and the fold change (designated in parenthesis) are indicated within graph bars. reg., regulation; pres., presynaptic; chem, chemical; syn., synaptic; pos., positive; proj., projection; diff., differentiation; neg., negative; sys., system; devel., development. $\boldsymbol{C}$, Cultured hippocampal neurons were stimulated or not with BDNF (50 ng/ml) for 10 min before preparation of cellular extracts. hnRNP K was immunoprecipitated from control and BDNF-treated hippocampal neuron homogenates, and the associated transcripts were identified by microarray analysis. The specificity of transcripts associated with hnRNP $\mathrm{K}$ was assessed by subtracting the levels of correspondent mRNAs pulled down together with mouse IgG antibodies. hnRNP $\mathrm{K}$-associated mRNAs were then compared between control and BDNF treated neurons. The results were obtained from the quantification of four different experiments performed in independent preparations, and are expressed as -log ( $p$ value) and log fold change (BDNF vs control). A total of 9509 transcripts showed a decrease in the interaction with hnRNP $\mathrm{K}$ in cells stimulated with BDNF; $p<0.05$ (gray dots) as determined by the paired Student's $t$-test. $\boldsymbol{D}$, Stimulation of cultured hippocampal neurons with BDNF does not affect total hnRNP K protein levels. Hippocampal neurons were stimulated with BDNF for 10, 20, and 30 min, and the cellular extracts were analyzed by Western blotting. $\beta$-Actin was used as loading control. The results represent quantification of three independent experiments, and are expressed as percentage (mean \pm SEM) of control. ns, nonsignificant as determined by ANOVA followed by Dunnett's multiple comparison test.

synaptic vesicles (Extended Data Table 1-3). Together, these data suggest that hnRNP K may act as a modulator of mRNA metabolism, to regulate plastic changes at excitatory synapses. It is also important to highlight the fact that among the identified mRNAs there are transcripts related with a wide variety of functions, processes and compartments (e.g., related with cytoskeleton, Golgi apparatus, nucleus, cell development and migration, protein ubiquitination; Extended Data Tables 1-2-4), confirming the key role of hnRNP $\mathrm{K}$ in the functional regulation of cells.

\section{Effect of BDNF stimulation on the interaction of hnRNP $\mathrm{K}$ with mRNAs}

In a gel-based proteome profiling of the effects of BDNF in cultured hippocampal neurons we observed a neurotrophin-induced upregulation of several protein spots identified as hnRNP K (Manadas et al., 2009), suggesting that this RNA-binding protein undergoes posttranslational modifications in neurons exposed to the neurotrophin. In particular, one of the up-regulated spots had a more acidic isoelectric point (pl) suggesting that hnRNP K may be phosphorylated on stimulation with BDNF.

Given the evidence pointing to posttranslational modifications in hnRNP $\mathrm{K}$ following stimulation of hippocampal neurons with BDNF, we investigated whether the neurotrophin-induced signaling regulates the interaction of the RNP with mRNAs using the RIP assay, as described above. Cultured hippocampal neurons were stimulated or not with BDNF (50 $\mathrm{ng} / \mathrm{ml} ; 10 \mathrm{~min})$, and the transcripts that were regulated by the neurotrophin were identified by comparing microarray data from hnRNP $\mathrm{K}$ immunoprecipitates obtained from BDNF-treated and nonstimulated hippocampal neurons. This comparison was performed after subtraction of microarray data corresponding to the unspecific binding obtained from the immunoprecipitates with mouse IgG antibodies. Calculation of the fold variation in RNA-hnRNP $K$ interaction induced by BDNF showed significant changes $(p<0.05)$ for 9509 transcripts. Remarkably, 9508 (99.9\%) transcripts were negatively regulated by BDNF and only $1(0.01 \%)$ of the mRNAs showed an increase in binding (Fig. 2C; Extended Data Table 1-5). This clearly shows a massive effect of
BDNF on the dissociation of mRNAs from hnRNP $K$ and/or hnRNP K-associated proteins. Control experiments showed no changes in total hnRNP K protein levels in hippocampal neurons stimulated with BDNF for 10-30 min, indicating that the effects of the neurotrophin on the interaction of RNP with the transcripts cannot be attributed to alterations in the total abundance of the protein (Fig. 2D).

The 9509 transcripts that were found to coimmunoprecipitate with hnRNP K by a mechanism sensitive to BDNFstimulation were also analyzed and distributed in three categories using the PANTHER classification system: biological processes, cellular component and molecular function (Tables 1-6-8). We also compared the most enriched biological process categories to which mRNAs associated with hnRNP $\mathrm{K}$ (control), and those that were regulated by BDNF (BDNF), belong (Fig. $2 A, B$ ). In this analysis we found that BDNF regulates preferentially hnRNP K-bound mRNAs that are involved in neuronal development, morphogenesis and differentiation (Fig. 2B). These findings are in agreement with the prominent role of hnRNP $\mathrm{K}$ in the posttranscriptional regulation of mRNAs crucial for axon outgrowth and development in Xenopus (Hutchins and Szaro, 2013). The stringent criteria used in this analysis (see methods section) excludes other functional and relevant enriched categories regulated by BDNF [e.g., regulation of synapse structure or activity (GO:0050803); 148 transcripts; 2.05-fold increase; - $\log _{10}$ $(p$ value $)=10.67572]$.

\section{BDNF modulates hnRNP $\mathrm{K}$ interaction with transcripts at the synapse}

Since hnRNP K may be localized at synaptic sites under resting conditions (Folci et al., 2014), we next validated the results obtained in the microarray studies regarding the effects of BDNF on the interaction of the RNA-binding protein with transcripts coding for proteins that are relevant in synaptic plasticity. These studies were performed in cultured hippocampal neurons (Fig. $3 A, B$ ) and in rat brain synaptoneurosomes, a subcellular fraction containing resealed presynaptic structures with attached sealed postsynaptic entities (Troca-Marín et al., 2010; Fig. 3C). The results were first validated for eight genes by qPCR, 
A

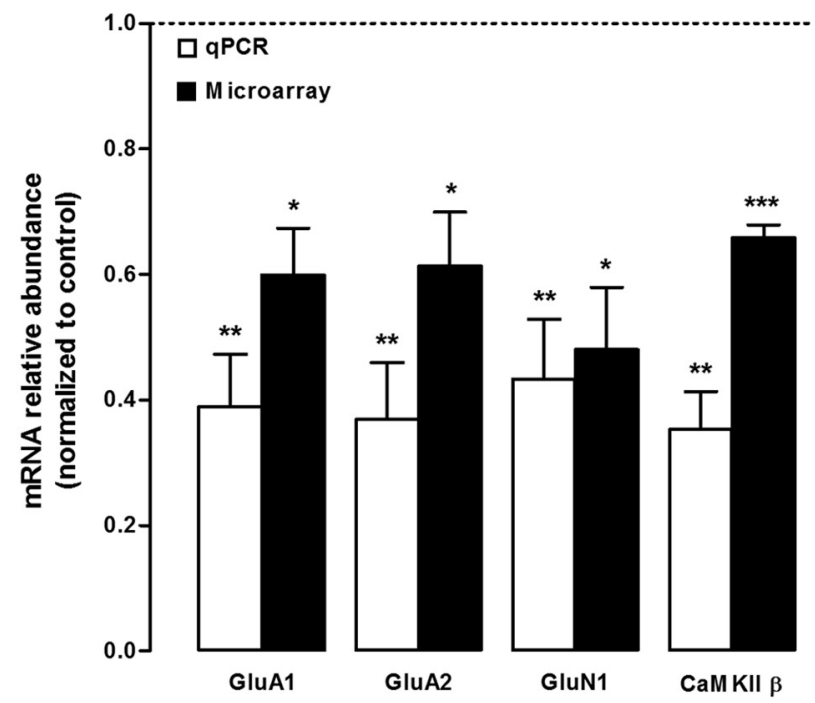

B

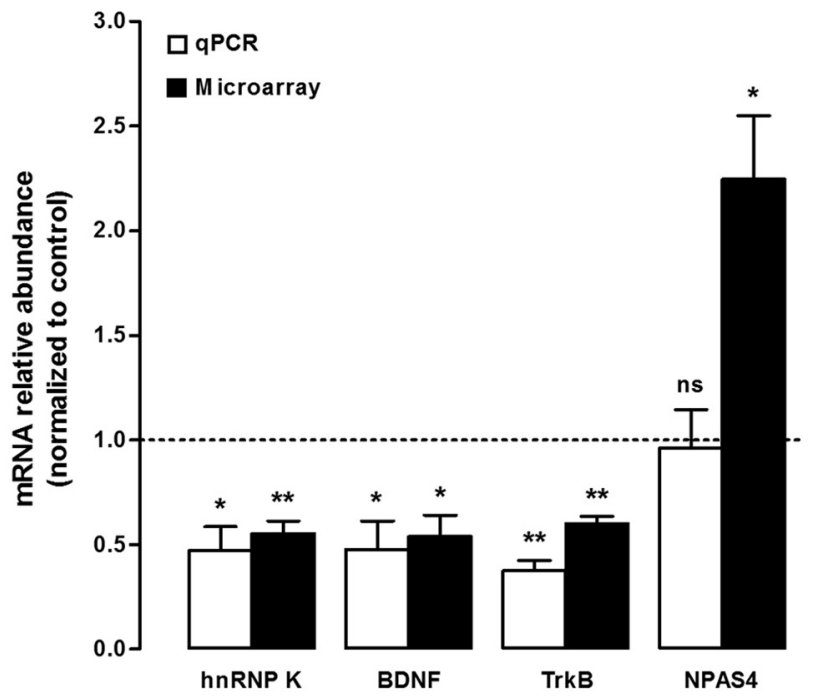

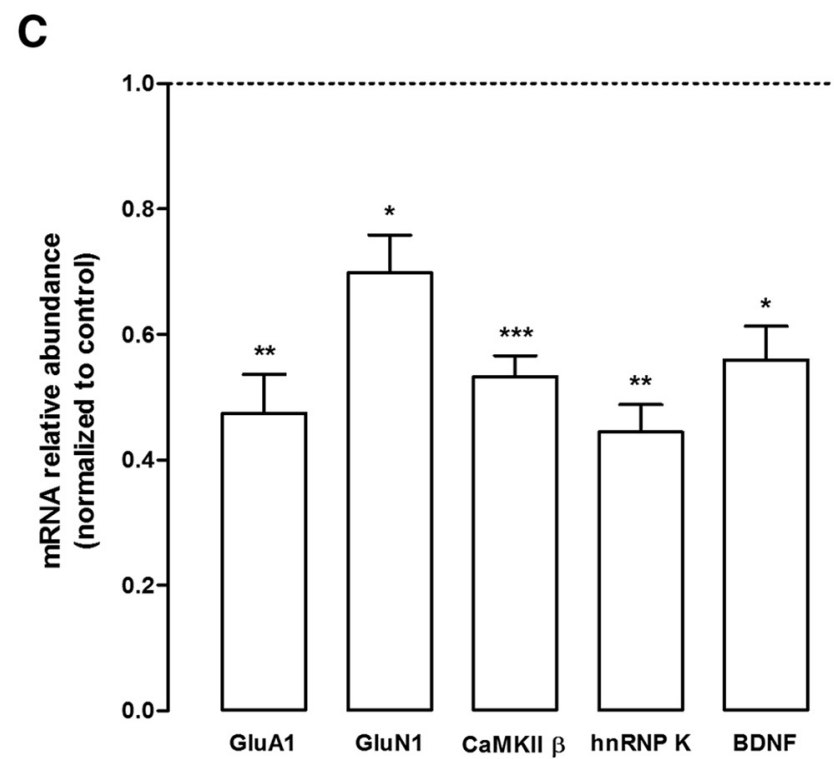

Figure 3. BDNF induces the dissociation of mRNA from hnRNP K at the synapse. $\boldsymbol{A}, \boldsymbol{B}$, Effect of BDNF stimulation (50 ng/ml; $10 \mathrm{~min}$ ) on transcript coimmunoprecipitation with hnRNP $\mathrm{K}$ in cultured hippocampal neurons as assessed by microarray and qPCR. The specificity of transcripts associated with hnRNP $\mathrm{K}$ was assessed by subtracting the levels of correspondent mRNAs pulled down together with mouse IgG antibodies. hnRNP K-associated mRNAs were then compared between control and BDNF treated neurons. A, Genes coding for synaptic proteins: GluA1, AMPA receptor subunit 1; GluA2, AMPA receptor subunit 2; GluN1, NMDAR subunit 1. B, Other genes: TrkB, tropomyosin-related kinase B receptor; NPAS4, neuronal PAS domain protein 4. The results represent quantitation of four different experiments performed in independent preparations, and are expressed as percentage [mean \pm SEM (qPCR) or SD (microarray)] of control; $* p<0.05, * * p<0.01, * * * p<0.001$ as determined by ANOVA followed by Dunnett's multiple comparison test (qPCR) or using the paired Student's $t$ test (microarray). $\boldsymbol{C}$, BDNF decreases the interaction of hnRNP $\mathrm{K}$ with mRNAs coding for synaptic proteins in hippocampal synaptoneurosomes. Synaptoneurosomes were stimulated or not with BDNF $(50 \mathrm{ng} / \mathrm{ml})$ for $10 \mathrm{~min}$ and the mRNA levels coimmunoprecipitated with hnRNP K (control and BDNF-treated synaptoneurosomes) were normalized to the correspondent IgG-pulled down mRNA to exclude any unspecific binding. Transcripts that were specifically associated with hnRNP K were then compared between control and BDNF-stimulated synaptoneurosomes. The relative abundance of each transcript was evaluated by qPCR. Results were normalized for mRNA expression under control conditions and are the average of at least four independent experiments. Statistical analysis was performed by one-way ANOVA followed by the Bonferroni's multiple comparison test; $* p<0.05 ; * * p<0.01 ; * * * p<0.001$. Extended data Figure 3-1 shows the characterization of the synaptosomal preparation, using specific protein markers. 
using cultured hippocampal neurons: (1) four genes coding for proteins with synaptic functions [GluA1 and GluA2 (AMPA receptor subunits), GluN1 (NMDAR subunit), and CaMKII $\beta$; Fig. 3A); (2) two genes involved in BDNF signaling (BDNF and TrkB; Fig. 3B); (3) hnRNP K; and (4) a mRNA that showed a very robust increase in the interaction of hnRNP $\mathrm{K}$ following stimulation of hippocampal neurons with BDNF (NPAS4; Fig. 3B). The results obtained in the qPCR experiments confirmed a BDNFinduced decrease in the interaction of hnRNP $\mathrm{K}$ with the transcripts for GluA1, GluA2, GluN1, BDNF, TrkB, hnRNP $K$, and CaMKII $\beta$. The only result obtained in the microarray experiments that was not validated by qPCR was the increase in the NPAS4 transcripts coimmunoprecipitated with hnRNP $\mathrm{K}$ in cells stimulated with BDNF.

To investigate whether BDNF induces the dissociation of transcripts from hnRNP $\mathrm{K}$ at the synapse, the interaction of the RNP with specific transcripts was investigated in hippocampal synaptoneurosomes, which are subcellular neuronal membrane fractions containing sealed presynaptic nerve endings attached to their corresponding postsynaptic counterparts (Extended Data Fig. 3-1). Stimulation of hippocampal synaptoneurosomes with BDNF (50 ng/ml; $10 \mathrm{~min}$ ) significantly decreased the interaction of the RNP with transcripts coding for GluA1, GluN1, CaMKII $\beta$, hnRNP K, and BDNF (Fig. 3C). Since synaptoneurosomes are a closed system, one may conclude that these effects are due to a local effect of BDNF rather than a global effect of the neurotrophin on gene expression.

To determine whether the effects of BDNF on the interaction of hnRNP K with the transcripts at the synapse is shared by other ligands that activate receptor tyrosine kinases, we compared the effect of the neurotrophin and the response to PDGF. In these experiments the mRNAs pulled-down with hnRNP $\mathrm{K}$ were normalized to the levels of mRNA pulled-down with IgG under the same conditions to exclude any unspecific binding. The levels of hnRNP K-bound transcripts obtained from PDGF- and BDNF-treated synaptoneurosomes were then compared to the control. Controls were obtained by incubating synaptoneurosomes for 10 min in the same buffer but without BDNF or PDGF. The PDGF receptors (PDGFR- $\beta$ ) and TrkB receptors activate similar signaling mechanisms, and PDGFR- $\beta$ receptors were shown to localize in pre- and postsynaptic sites in the hippocampus where they mediate LTP (Shioda et al., 2012). In contrast with the effect of BDNF (50 ng/ml; $10 \mathrm{~min}$ ), which decreases the coimmunoprecipitation of hnRNP K with mRNA for GluA1, GluN1, and BDNF, stimulation of hippocampal synaptoneurosomes with PDGF did not change the interaction of the RNP with GluA1 and BDNF transcripts, and enhanced the amount of GluN1 transcripts pulled down together with hnRNP K (Fig. 4A). Control experiments showed that BDNF and PDGF activate the ERK and Akt signaling pathways under the experimental conditions used, as determined by Western blotting with antibodies against pAkt and pERK1/2 (Fig. 4B,C). Together, these results indicate that BDNF-induced signaling is specifically coupled to the regulation of hnRNP $\mathrm{K}$ interaction with transcripts coding for GluA1, GluN1, and BDNF.

\section{HFS-induced LTP in the DG differentially modulates the interaction of hnRNP $\mathrm{K}$ with the transcripts}

To investigate whether hnRNP K-associated mRNAs are regulated by synaptic activity in vivo, we use a model of HFS-induced LTP in the DG of live anesthetized rats (Fig. $5 A)$. The LTP at medial perforant path-granule cell synapses induced by HFS prompts the transport of different mRNAs into dendrites (Steward et al., 1998; Messaoudi et al., 2007; Panja et al., 2009; Dziembowska et al., 2012), and the maintenance of this form of LTP is sensitive to the BDNF scavenger TrkB-Fc (Fig. 6A; Panja et al., 2014). The medial perforant path fibers in the angular bundle were unilaterally stimulated and the evoked fEPSPs were recorded in the hilar region of the DG (Fig. 5A). LTP was induced by spaced stimulation consisting of three sessions of HFS $(400 \mathrm{~Hz}$, eight pulses) with 5 min between sessions. This paradigm induces a robust and sustained increase in the fEPSP (Fig. $5 A)$. The DG was dissected immediately after the experiments (at $t=30$ min after HFS) and the tissue was processed to analyze the changes in total abundance of transcripts coding for hnRNP K, GluA1, GluN1, and BDNF, as well as for their coimmunoprecipitation with hnRNP K. qPCR experiments showed that HFS induces a massive increase in the total abundance of BDNF mRNA, and significantly increased total GluN1 mRNA levels. No significant effect was observed for total GluA1 and hnRNP $\mathrm{K}$ total mRNA under the same conditions (Fig. 5B). HFS resulted in a decrease in hnRNP $\mathrm{K}$ and GluN1 mRNA levels associated with hnRNP $\mathrm{K}$ protein (Fig. $5 \mathrm{C}$ ), indicating that synaptic activity induces the dissociation of hnRNPK-bound mRNAs in vivo. In contrast, BDNF mRNA levels were increased in the coimmunoprecipitates at 30-min post-HFS (Fig. 5C), possibly due to the massive increase in the total abundance of these transcripts induced by HFS. No differences in hnRNP $\mathrm{K}$ total protein levels were observed 30 -min post-HFS (Fig. $5 D$ ) as determined by Western blotting, demonstrating that the observed alterations in the amount of mRNAs associated with the hnRNP K cannot be attributed to differences in the abundance of the RNP.

The HFS-induced LTP in the DG in vivo is partly mediated by TrkB signaling, as observed in experiments using TrkB-Fc, an effective extracellular scavenger of TrkB ligands. Intrahippocampal infusion of TrkB-Fc (1 $\mu$ l, 100 $\mu \mathrm{g}, 12.5 \mathrm{~min})$ before HFS abrogated the increase in the magnitude of the fEPSP slope when compared to IgG-Fc infused control and the noninfused control (Fig. 6A). In control experiments using IgG-Fc, HFS reduced the amount of hnRNP K, GluN1, and GluA1 transcripts coimmunoprecipiated with hnRNP K (Fig. 6B), in accordance to the results of Figure $5 A$. Importantly, on TrkB-Fc infusion, HFS did not affect the interaction of hnRNP $\mathrm{K}$ with the GluN1, GluA1, and hnRNP K mRNAs (Fig. 6C), showing a key role for TrkB signaling in the regulation of the RNP interaction with the transcripts after induction of LTP. The total levels of hnRNP K, GluA1, and GluN1 mRNA did not change in the DG on HFS in the presence 
A

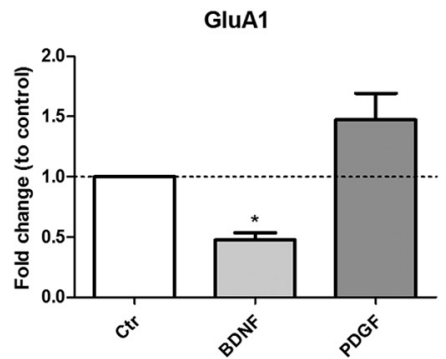

GluN1

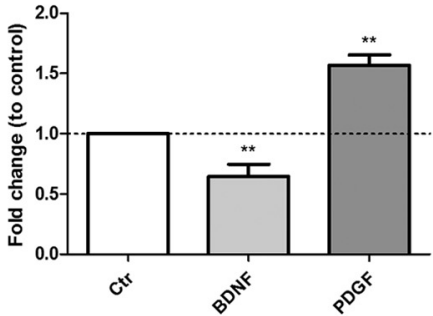

B
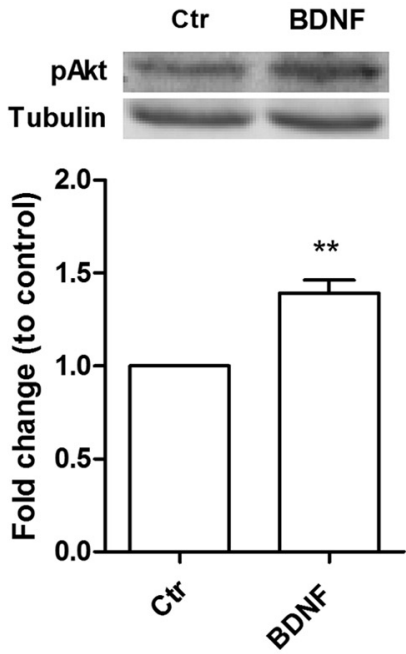

Ctr
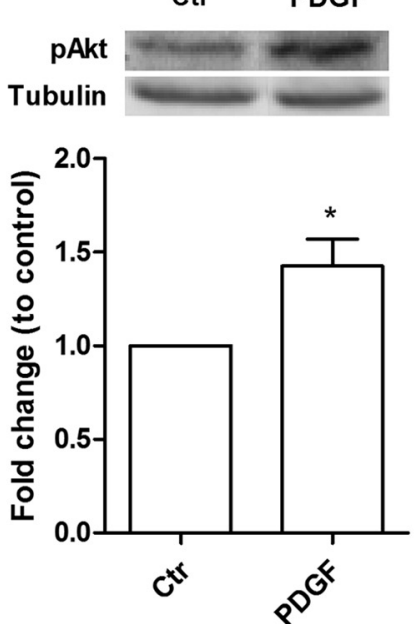

Ctr
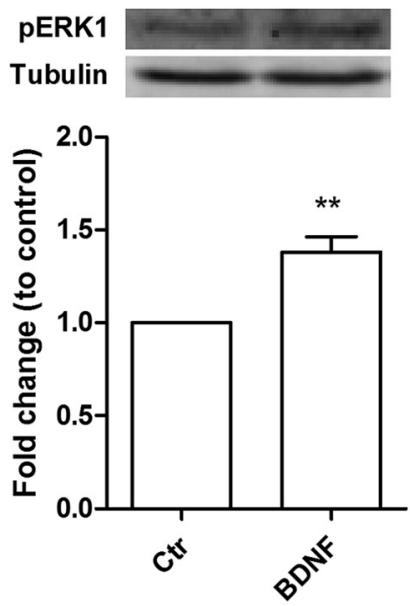

Ctr PDGF

pERK1

Tubulin

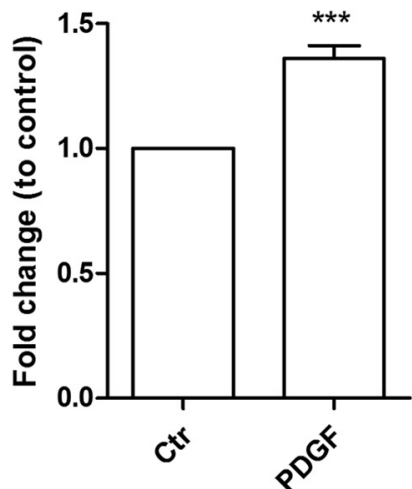

BDNF

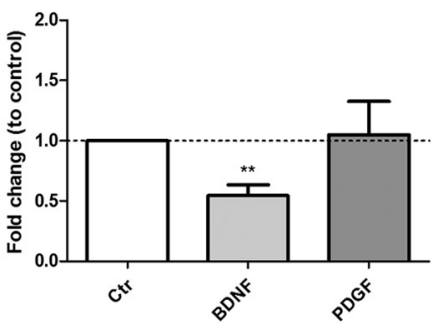

Ctr

BDNF
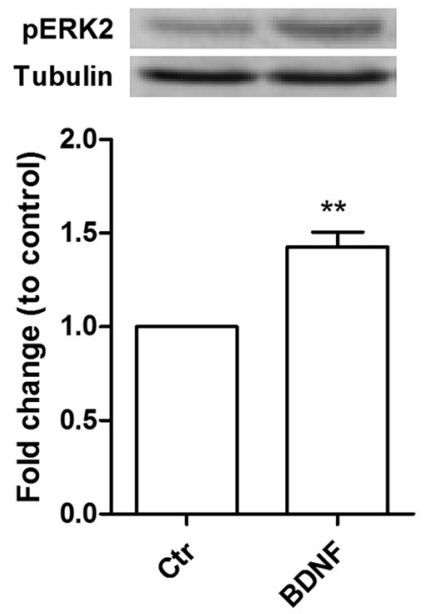

Ctr

PDGF

Tubulin

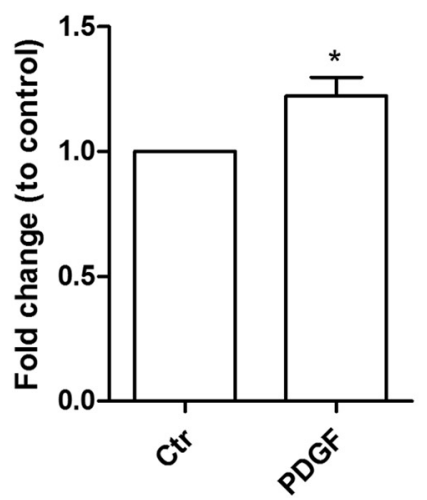

Figure 4. BDNF signaling specifically induces the release of mRNAs from hnRNP K-containing complexes at synaptic sites. $\boldsymbol{A}$, Effect of BDNF and PDGF on the interaction of GluA1, GluN1, and BDNF mRNAs with hnRNP $\mathrm{K}$ in synaptoneurosomes. The relative abundance of each mRNA coimmunoprecipitated with hnRNP K was evaluated by qPCR. Results are the mean \pm SEM of four different experiments performed in independent preparations, and are expressed as fold change to control; $* p<0.05, * * p<0.01$, as determined by one-way ANOVA followed by the Dunnett's multiple comparison test. Activation of Akt and ERK1/2 by BDNF (B) and PDGF $(\boldsymbol{C})$ in hippocampal synaptoneurosomes. Graphs represent the fold change in the levels of pAkt, pERK1, or pERK2 in hippocampal synaptoneurosomes stimulated with BDNF $(50 \mathrm{ng} / \mathrm{ml})$ or PDGF $(20 \mathrm{ng} / \mathrm{ml})$ for 10 min. Representative Western blotting images showing the results obtained for the phosphorylated proteins and tubulin under control conditions and following stimulation with BDNF or PDGF, as indicated. The results represent the quantification of six to nine experiments performed in independent preparations, and are expressed as fold change (mean \pm SEM) to control; $* p<0.05, * * p<0.01, * * * p<0.001$ as determined by the Student's $t$ test. 
A

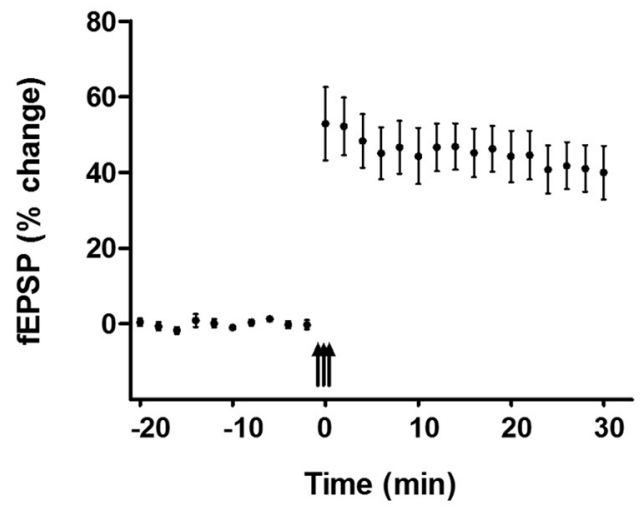

C

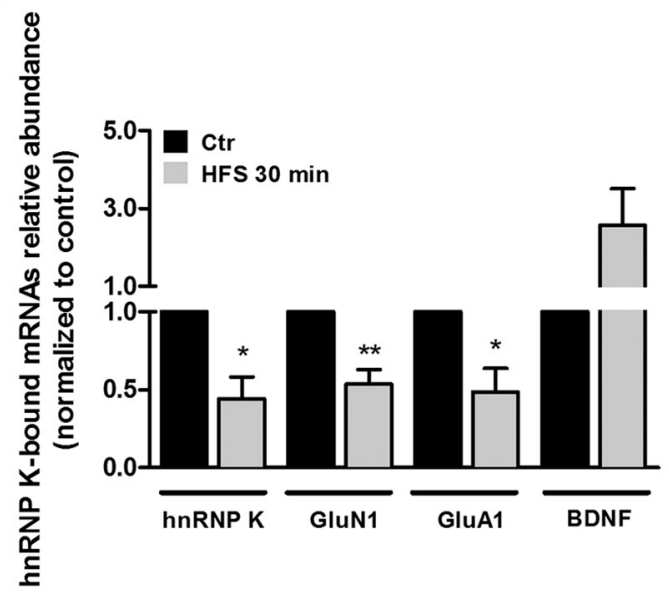

B

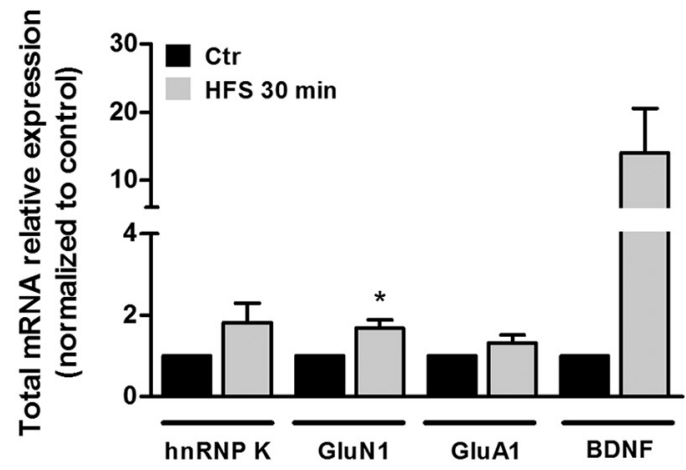

D

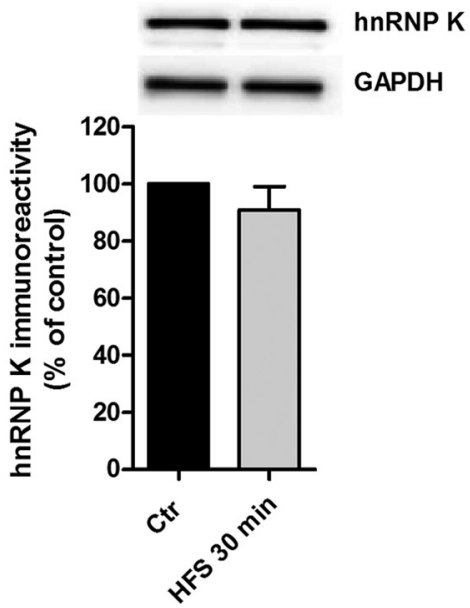

Figure 5. LTP-induced regulation of hnRNP K-associated mRNAs in vivo. Experiments were performed in live anesthetized rats. Electrodes were positioned for selective unilateral stimulation of the medial perforant path fibers in the angular bundle and recording of the evoked field potentials in the hilar region of the DG. $\boldsymbol{A}$, Time course plots showing changes in the medial perforant path-evoked fEPSP slope expressed as percentage of baseline. Values are means \pm SEM. Test pulses were applied at $0.033 \mathrm{~Hz}$. The HFS paradigm (indicated by arrows) consisted of eight pulses of $400 \mathrm{~Hz}$, repeated four times at 10-s intervals. Three sessions of HFS were given at intervals of five min. $n=6$ for each time point. $\boldsymbol{B}$, The variation of hnRNP K, GluN1, GluA1, and BDNF mRNA levels was assayed by qPCR using total RNA samples obtained from DG homogenates collected 30-min post-HFS and the nonstimulated contralateral control tissue. The results are presented as mean \pm SEM normalized to the contralateral nonstimulated DG, and Hprt1 (hypoxanthine guanine phosphoribosyl transferase 1) was used as internal control gene. Results are the average \pm SEM of six experiments $(n=6 \mathrm{DG})$ analyzed in three independent preparations; $* p<0.05$ as determined by Student's $t$ test. $\boldsymbol{C}$, The levels of hnRNP K, GluN1, GluA1, and BDNF transcripts coimmunoprecitated with hnRNP K were assayed by qPCR. hnRNP K protein was immunoprecipitated from equal amounts $(500 \mu \mathrm{g})$ of total extracts from homogenized DG collected 30-min post-HFS and the contralateral tissue. Results are presented as mean \pm SEM normalized to the contralateral DG and are the average \pm SEM of six experiments ( $n=6 \mathrm{DG}$ ) analyzed in three independent preparations; $* * p<0.01 ; * p<0.05$ as determined by the Student's $t$ test. $\boldsymbol{D}, \mathrm{hnRNP} \mathrm{K}$ protein levels were measured by Western blotting using DG homogenate samples collected 30 -min post-HFS and the contralateral nonstimulated tissue. The results are the average \pm SEM of six experiments $(n=6 \mathrm{DG})$ analyzed in three independent preparations and are presented as the percentage change in hnRNP K protein levels in the treated DG relative to the nonstimulated contralateral tissue. GAPDH was used as loading control.

of IgG-Fc, while an increase in BDNF transcripts was observed (Fig. 6D). Similar results were obtained after injection of TrkB-Fc, with the exception of a downregulation of GluA1 mRNA (Fig. 6E). Altogether these results indicate that the activity-induced regulation of hnRNP $\mathrm{K}$-associated $\mathrm{mRNAs}$ requires TrkB signaling in vivo.

\section{Downregulation of hnRNP K decreases the amplitude of NMDAR-mediated mEPSC}

BDNF is known to enhance the activity of postsynaptic NMDAR in cortical and hippocampal pyramidal neurons
(Kolb et al., 2005; Madara and Levine, 2008). Given the results showing the dissociation of transcripts bound to hnRNP $\mathrm{K}$ on stimulation of synaptoneurosomes with BDNF (e.g., GluN1; see Figure 3C), we hypothesized that the RNP may play a role in the modulation of postsynaptic NMDAR by the neurotrophin. To address this hypothesis, we tested the effect of BDNF on the amplitude of NMDAR-mediated mEPSCs, and hnRNP $\mathrm{K}$ was downregulated using a specific shRNA (sh-hnRNP K). Figure $7 A, B$ show that sh-hnRNP $\mathrm{K}$ expression for $3 \mathrm{~d}$ 
A

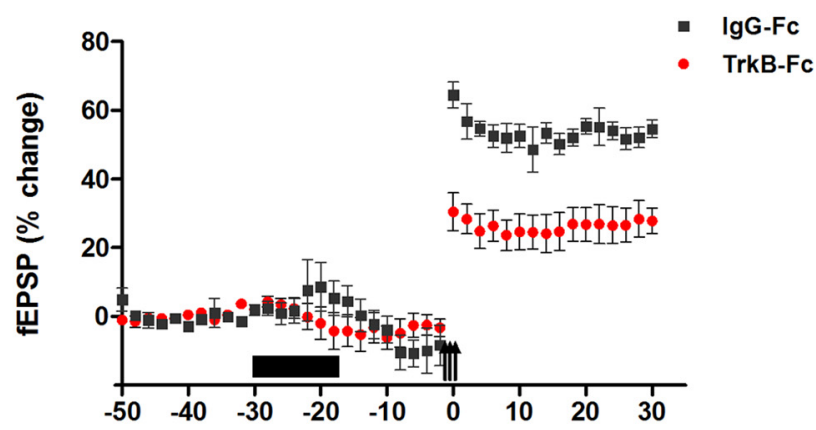

B

D

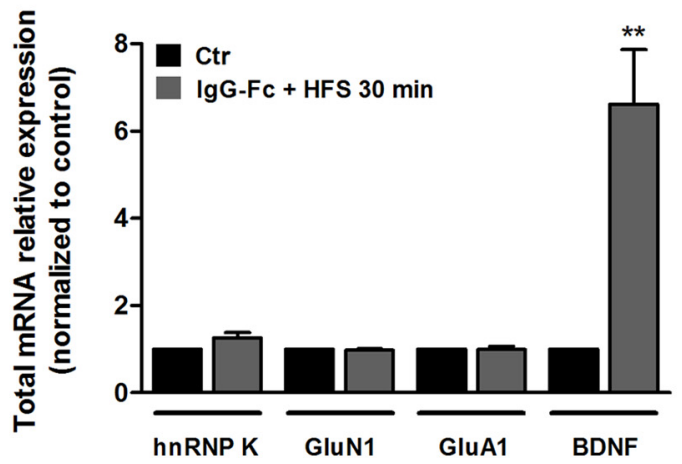

C

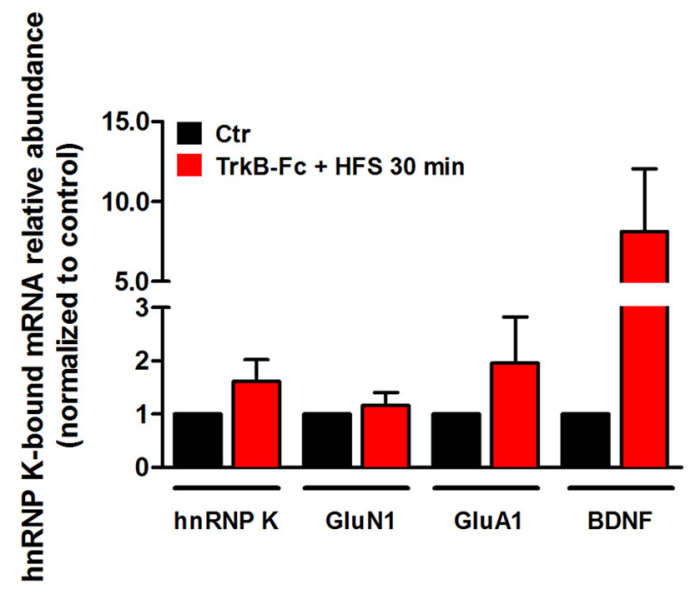

E

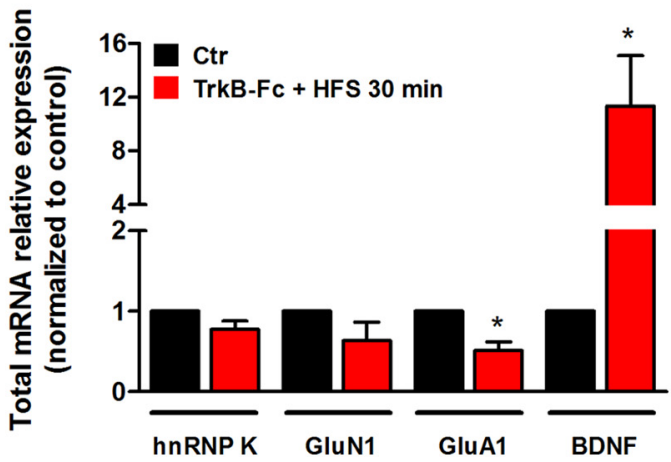

Figure 6. BDNF signaling is required for LTP maintenance and LTP-induced alterations in mRNA interaction with hnRNP K. $\boldsymbol{A}$, Time-course plots showing changes in the medial perforant path-evoked fEPSP in rats receiving TrkB-Fc $(1 \mu \mathrm{l}, 100 \mu \mathrm{g})$ or lgG-Fc (1 $\mu \mathrm{l}, 100 \mu \mathrm{g}$ ) infusion before HFS (arrows). Values are means \pm SEM and are expressed in percentage of the baseline. Test pulses were applied at $0.033 \mathrm{~Hz}$. HFS was applied in three series of $400-\mathrm{Hz}$ bursts separated by 5 min. TrkB-Fc $(1 \mu \mathrm{l}, 100 \mu \mathrm{g} ; n=6)$ or lgG-Fc $(1 \mu \mathrm{l}, 100 \mu \mathrm{g} ; n=6)$ were infused in the dorsal DG at $0.08 \mu \mathrm{l} / \mathrm{min}$ during the period indicated by the black bar. Test pulses were not given during the HFS period. $\boldsymbol{B}, \boldsymbol{C}$, The levels of hnRNP K, GluN1, GluA1, and BDNF mRNAs coimmunoprecipitated with hnRNP K were assayed by qPCR in DG homogenates obtained from $(\boldsymbol{B}) \operatorname{lgG}-\mathrm{Fc}(n=6)$ and $(\boldsymbol{C})$ TrkB-Fc $(n=6)$ infused rats at 30 -min post-HFS. Results are presented as mean \pm SEM normalized to the correspondent contralateral DG. $\boldsymbol{D}, \boldsymbol{E}$, The variation of total hnRNP K, GluN1, GluA1, and BDNF mRNA levels in $(\boldsymbol{D}) \operatorname{lgG}-\mathrm{Fc}(n=6)$ and $(\boldsymbol{E})$ TrkB-Fc $(n=6)$ infused rats was assayed by qPCR in DG homogenates obtained at 30-min post-HFS. Results are presented as mean \pm SEM normalized to the correspondent contralateral nonstimulated DG, and Hprt1 was used as internal control gene; *p $<0.05 ; * * p<0.01$, as determined by the paired Student's $t$ test.

decreases hnRNP $\mathrm{K}$ in the dendritic compartment by $33.3 \%$, while a scramble shRNA which does not target a specific sequence (sh-scramble) was without effect. Importantly, the shRNA targeting hnRNP K decreases
hnRNP K protein levels but does not affect the expression of another member of the hnRNP family of proteins, hnRNP A2/B1 (Fig. 7C), proving the specificity of the knockdown. 
A

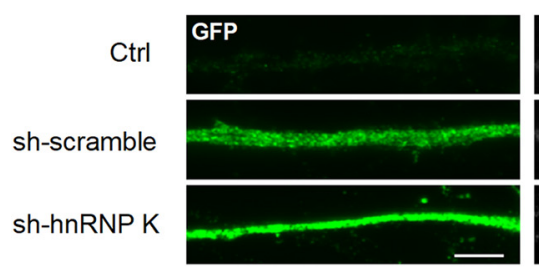

D
B
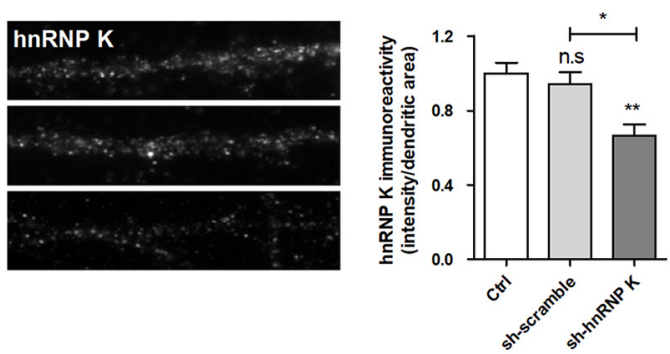

C

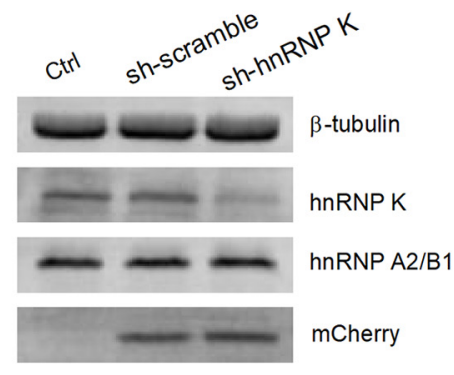

E

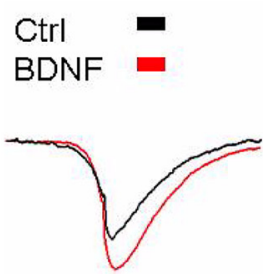

CTRL

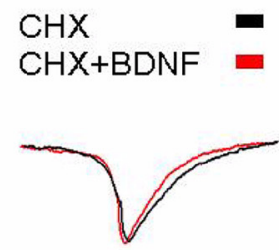

$5 \mathrm{pA}$

$10 \mathrm{~ms}$

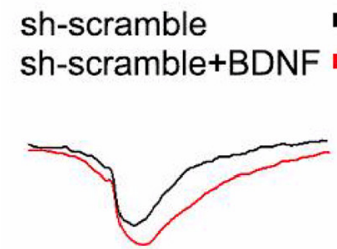

$5 \mathrm{pA}$

sh-hnRNP K

sh-hnRNP K+BDNF

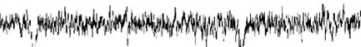

$\mathrm{CHX}$

sh-scramble

sh-hnRNP K

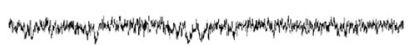

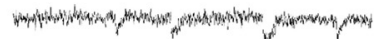

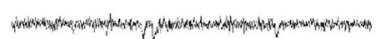

BDNF

$\mathrm{CHX}+\mathrm{BDNF}$

sh-scramble+BDNF

sh-hnRNP K+BDNF

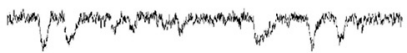

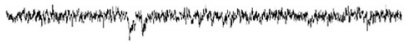

4hily

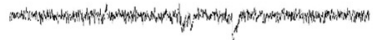

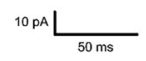

F

G
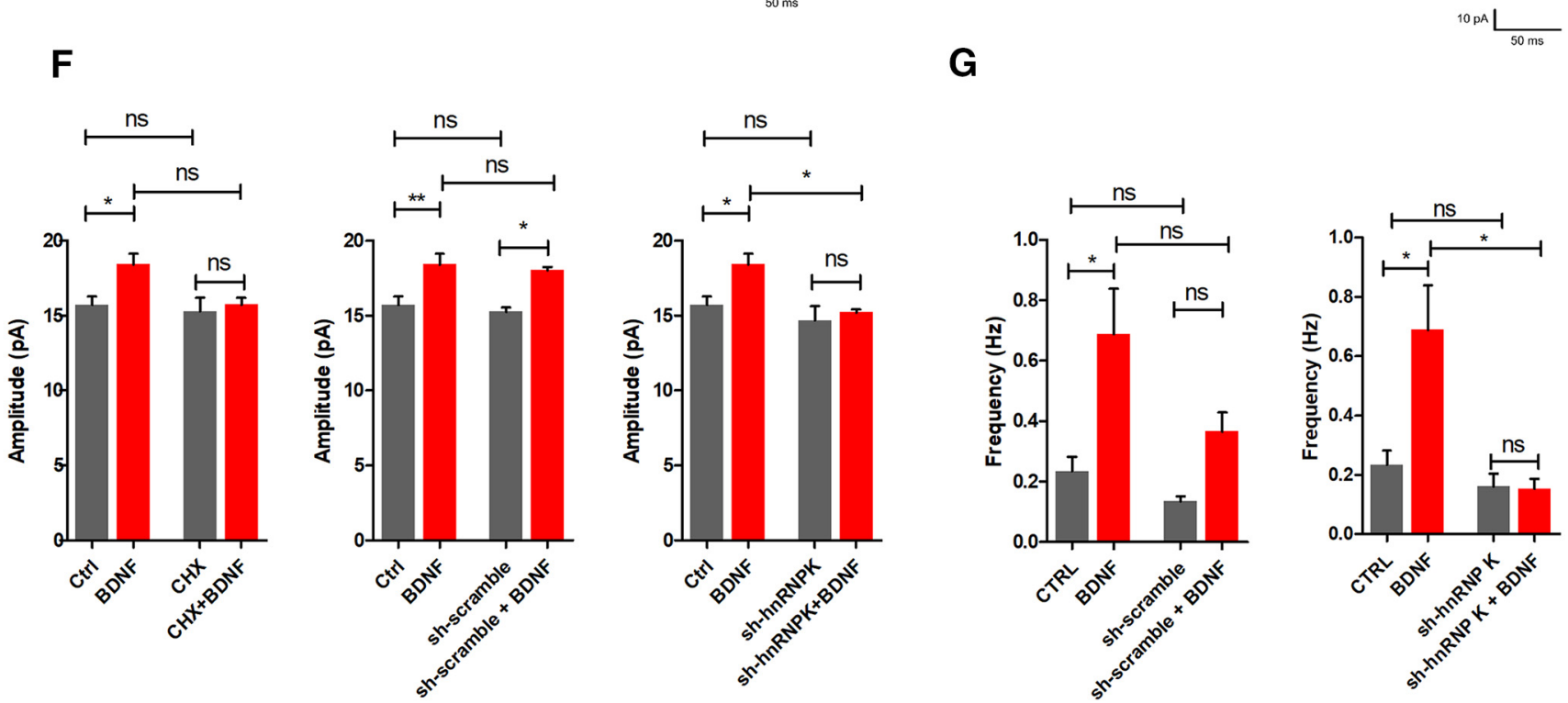

Figure 7. BDNF upregulates NMDAR-mediated mEPSC by a mechanism dependent on hnRNP K. $\boldsymbol{A}$, Low-density cultured hippocampal neurons were transduced with shRNA (sh-hnRNP K; sh-scramble, which does not target a specific sequence) constructs at DIV11. The cells were fixed at DIV14 and then immunostained for hnRNP K (gray), GFP (green), and MAP2 (not shown 


\section{continued}

in the figure). The hnRNP K immunoreactivity was measured in dendrites $(\boldsymbol{A}, \boldsymbol{B})$, using the Image software. Results are normalized to control and are the average of three to four different experiments performed in independent preparations (19-34 cells analyzed in neurons expressing the shRNAs for $3 \mathrm{~d}$ ). $\boldsymbol{C}$, Western blot analysis of hnRNP K, hnRNP A2/B1, $\beta$-tubulin (loading control), and mCherry (infection control), in cultured hippocampal neurons transduced or not with sh-hnRNP $\mathrm{K}$ and sh-scramble constructs. $\boldsymbol{D}$, $\boldsymbol{E}$, NMDAR-mediated mEPSC were recorded under control conditions $(n=13)$ and after 30 min of stimulation with BDNF (50 ng/ml; $n=14)$. Where indicated, the cells were transfected with sh-scramble $(n=6)$ or sh-hnRNP K $(n=6)$, or incubated with cycloheximide $(50 \mu \mathrm{g} / \mathrm{ml})$. The cells were preincubated with the translation inhibitor for 15 min before stimulation with BDNF. Cells transfected with sh-hnRNP K or incubated with cycloheximide showed no significant increase in the amplitude of NMDAR-mediated mEPSC on BDNF treatment, while the scramble shRNA was without effect $(\boldsymbol{F})$. Analysis of NMDAR-mediated mEPSC frequency in nontransfected cells $(n=12)$ and cells transfected with sh-sramble $(n=8)$ or sh-hnRNP K $(n=6)$, under control conditions and following BDNF stimulation (G). The average mEPSC traces recorded are shown in $\boldsymbol{D}$ and representative traces are shown in $\boldsymbol{E}$. Results are presented as mean \pm SEM for the indicated number of experiments. Statistical analysis was performed by one-way ANOVA, followed by Bonferroni's multiple comparison test. n.s., not significant; $* p<0.05 ; * * p<0.01$. Scale bar: $5 \mu \mathrm{m}$.

NMDAR-mediated mEPSC were recorded in the absence of presynaptic stimulation and in the presence of TTX, resulting from the spontaneous release of glutamate from nerve terminals. Furthermore, NMDAR-dependent synaptic responses were pharmacologically isolated by blocking AMPA and GABA receptors, and by supplementing the salt solution with the NMDAR coagonist glycine. The postsynaptic NMDAR-mediated component was expressed by using a salt solution lacking $\mathrm{Mg}^{2+}$, which allowed recording the mEPSC activity at a physiological holding potential of $-60 \mathrm{mV}$. Alterations in the number of NMDAR at the synapse are expected to correlate with changes in the amplitude of mEPSC. Incubation of cultured hippocampal neurons with BDNF $(50 \mathrm{ng} / \mathrm{ml} ; t>30$ $\mathrm{min}$ ) increased the amplitude of mEPSC, and this effect was abrogated by transfection with sh-hnRNP K (Fig. $7 D-F)$. In contrast, an increase in the mEPSC amplitude was observed in cells transfected with the control shRNA (sh-scramble) when stimulated with BDNF (Fig. 7D-F). Interestingly, downregulation of hnRNP $\mathrm{K}$ was without effect on the NMDAR-mediated mEPSC measured in the absence of BDNF (Fig. 7D-F).

The results showing a role for hnRNP $K$ in the regulation of NMDAR-mediated mEPSC by BDNF may be due to the release of transcripts which will become available for translation. This hypothesis was tested by evaluating the effect of cycloheximide, an inhibitor of protein synthesis, on the NMDAR-mediated mEPSC, under control and in hippocampal neurons stimulated with BDNF. Inhibition of protein synthesis abrogated the BDNF-induced increase in the amplitude of mEPSC mediated by NMDAR. However, it was without effect when the NMDAR currents were measured under resting conditions (Fig. 7D-F).

Several lines of evidence now demonstrate that BDNF may increase $\mathrm{mESPCs}$ frequency via presynaptic mechanisms (Carvalho et al., 2008). In agreement with these findings, we also observed a significant increase on NMDAR-mediated mESPSCs frequency following BDNF treatment (Fig. 7G) which was not observed after hnRNP $\mathrm{K}$ downregulation (Fig. 7G). Neurons transfected with a scramble construct showed a modest increase in NMDAR-mediated mESPC frequency on exogenous application of BDNF (Fig. 7G).

\section{Discussion}

In this work, we identified a large number of mRNAs, belonging to different categories, including transcripts coding for synaptic proteins, in hnRNP K immunoprecipitates from cultured hippocampal neurons. Stimulation with BDNF induced a massive dissociation of a subpopulation of transcripts that coimmunoprecipitate with hnRNP K, suggesting that this RNP is a major mediator of the effects of BDNF on translation activity in hippocampal neurons. This hypothesis is also supported by the results showing a BDNF-dependent dissociation of several transcripts from hnRNP K following HFS of the DG synapses. Some of the regulated transcripts code for proteins relevant for the plasticity of glutamatergic synapses (GluN1, GluA1, BDNF, and CamKII $\beta$; Santos et al., 2010; Huganir and Nicoll, 2013; Fan et al., 2014; Leal et al., 2014a; Kim et al., 2016), and BDNF had a similar effect in hippocampal synaptoneurosomes, suggesting a role for these regulatory mechanisms in the modulation of local protein synthesis required for LTP maintenance. Accordingly, downregulation of hnRNP K impaired the effects of BDNF in enhancing NMDAR-mediated mEPSC, and similar effects were obtained on inhibition of translation activity.

Under resting conditions, we identified 16,015 transcripts present in the hnRNP $\mathrm{K}$ immunoprecipitates, coding for proteins involved in different biological processes, and with distinct molecular functions and cellular localization, as described with GO. It is remarkable that genes related with excitatory synaptic plasticity are highly represented in the group of transcripts coimmunoprecipitated with hnRNP $\mathrm{K}$ in extracts prepared from cultured hippocampal neurons. From the list of mRNAs that were specifically pulled-down together with hnRNP $\mathrm{K}$ in extracts prepared from hippocampal neurons under resting conditions, only $59.4 \%$ showed a significant change in the interaction with the RNP following stimulation with BDNF. This shows that the signaling mechanisms activated by the neurotrophin target a specific subpopulation of transcripts, rather than having a global effect. Furthermore, with the stringent analysis here performed, we found that mRNAs regulated by BDNF belong preferentially to GO categories related with neuronal development and morphogenesis, although other functional relevant categories are enriched to a similar extent. Importantly, all transcripts showing a change in interaction with hnRNP $K$ following 
stimulation with BDNF were dissociated from the RNP, and no mRNA showed an increased binding in hippocampal neurons stimulated with the neurotrophin. hnRNP K has numerous putative phosphorylation sites, some of them located in the $\mathrm{KH}$ domains responsible for RNA and DNA binding (Bomsztyk et al., 2004). Since previous studies have shown that the interaction of hnRNP $\mathrm{K}$ with mRNAs is regulated by the phosphorylation state of the protein (Ostareck-Lederer et al., 2002; Iwasaki et al., 2008; Laursen et al., 2011; Tahir et al., 2014), it may be hypothesized that the phosphorylation of specific amino acid residues accounts for the observed BDNF-evoked dissociation of transcripts from the RNP. Phosphorylation of hnRNP $K$ at an ERK phosphorylation site located within the $\mathrm{KI}$ domain was shown to promote the translation of mRNA of axonal cytoskeleton proteins that interact with the RNP (Hutchins et al., 2015). The transcripts that remain associated with hnRNP $\mathrm{K}$ following stimulation of hippocampal neurons with BDNF may interact with a different region of the RNA-binding protein, which may account for a differential regulation.

The group of transcripts dissociated from hnRNP K following stimulation of hippocampal synaptoneurosomes with BDNF included mRNAs coding for AMPA (GluA1) and NMDA (GluN1) receptor subunits, in addition to CaMKII $\beta$ and BDNF, which play important roles in LTP of glutamatergic synapses. Furthermore, HFS-induced LTP in the DG was also accompanied by a dissociation of the GluA1 and GluN1 mRNA from hnRNP $K$ through a BDNFdependent mechanism, providing evidence for a similar role of BDNF in vivo. It may be hypothesized that after being released from hnRNP K, the transcripts will become available for local translation at the synapse thereby contributing to synaptic potentiation. Accordingly, stimulation with BDNF was shown to up-regulate GluA1 (Schratt et al., 2004), CaMKII $\beta$ (Liao et al., 2007), and Homer2 (Schratt et al., 2004) protein levels in synaptoneurosomes. GluN1 mRNA is also among the RNAs that are present in both soma and dendrites (Benson, 1997; Gazzaley et al., 1997; Pal et al., 2003), and is associated with RNA granules (Krichevsky and Kosik, 2001), but the effects of BDNF on the expression levels of this receptor subunit at the synapse has not been yet reported. A similar role for hnRNP $\mathrm{K}$ in the release of transcripts used for local translation may be hypothesized in the BDNF-induced dendritic synthesis of BDNF and TrkB receptors (Shiina et al., 2005; Baj et al., 2016), and in the translation of the hnRNP $\mathrm{K}$ mRNAs at the synapse (Liao et al., 2007). The local synthesis of RNA-binding proteins at the synapse, including hnRNP $\mathrm{K}$, following stimulation with BDNF is an intriguing observation, but it may contribute to increasing the local buffering capacity of the transcripts released after the disassembly of the RNA granules, thereby contributing to the stabilization of the mRNAs. The newly synthesized protein may also play a role in cytoskeleton regulation (Yoo et al., 2006).

In contrast with the results obtained in cultured neurons and in hippocampal synaptoneurosomes, in vivo HFS of medial perforant path fibers enhanced the interaction of BDNF mRNA with the RNA-binding protein. This may be attributed to the massive increase in the total amount of transcripts for BDNF, as observed in the qPCR experiments from total DG extracts, due to the activitydependent upregulation of the BDNF gene (Patterson et al., 1992; Bramham et al., 1996). Our findings in synaptoneurosomes indicate that BDNF triggers the release of $B D N F$ mRNA from the hnRNP $\mathrm{K}$ complex, making the $B D N F$ mRNA available for local translation (Vanevski and Xu, 2015; Baj et al., 2016). During DG LTP, sustained translation of BDNF mRNA is observed in the synaptoneurosome fraction (Panja et al., 2014). This release of BDNF mRNA from hnRNP K may provide a continuous supply of BDNF transcripts, and a consequent sustained (hours) activation of the BDNF-TrkB signaling, which is required for the consolidation of LTP in the DG of live rodents (Panja et al., 2014) as well as in CA1 synapses (Kang et al., 1997).

The mRNA for the NMDAR subunit GluN1 was among the transcripts that showed a decrease in coimmunoprecipitation with hnRNP $\mathrm{K}$ following stimulation of hippocampal neurons or synaptoneurosomes with BDNF, and similar results were obtained in the DG after HFS of medial perforant path fibers. Since the mRNAs coding for other subunits of NMDAR were also dissociated from the hnRNP $\mathrm{K}$ following stimulation with BDNF, this may contribute to the local synthesis of receptors. According to this hypothesis, stimulation of cultured hippocampal neurons with BDNF upregulated the NMDAR-mediated mEPSCs by a hnRNP K-dependent mechanism, which was also sensitive to the protein synthesis inhibitor cycloheximide. This effect is likely to result from an upregulation in the synaptic expression of NMDAR, and may account for synaptic facilitation on incubation of hippocampal neurons with BDNF (Kang and Schuman, 1996; Santos et al., 2015) as well as for LTP following HFS (Korte et al., 1995; Korte et al., 1996; Kang et al., 1997; Minichiello et al., 1999; Panja et al., 2014). Together, our data points to a key role of hnRNP K in BDNF-induced synaptic plasticity events which is likely related with effects of the neurotrophin on hnRNP K-associated mRNAs, although we cannot not exclude any other putative functions of hnRNP K (e.g., nuclear effects). Interestingly, downregulation of hnRNP K selectively impaired the BDNF-induced enhancement of the NMDAR-mediated mEPSC, as it was without effect on the currents measured under resting conditions. These results suggest that BDNF recruits a distinct pool of receptors, which are synthesized de novo as indicated by the results obtained in the presence of cycloheximide. A similar mechanism may be involved in the delivery of GluA1-containing AMPA receptors to the membrane on stimulation with BDNF, since (1) it is a newly synthesized pool of receptors that is readily incorporated on the plasma membrane (Fortin et al., 2012) and (2) our results showed a dissociation of GluA1 mRNA from hnRNP $K$ in synaptoneurosomes incubated with the neurotrophin. Similarly, protein synthesis may also be involved in the increase in GluA1 surface expression under conditions that induce chemical LTP (Folci et al., 2014).

BDNF was also observed to enhance the frequency of mEPSC in accordance with previous reports (Carvalho 
et al., 2008), and this effect was abrogated on knockdown of hnRNP K. Although this RNA-binding protein is present and plays a role at presynaptic sites (Liu and Szaro, 2011; Hutchins et al., 2015), the effect of hnRNP K knockdown on the frequency of NMDAR-mediated mRPSC is likely to involve a postsynaptic mechanism as transfected neurons receive inputs from untransfected cells.

In contrast with the effect of BDNF, activation of the receptors for PDGF (PDGFR- $\beta$ ), which also belong to the receptor tyrosine kinase family, did not decrease the interaction of hnRNP $\mathrm{K}$ with GluA1, GluN1, and BDNF mRNAs. This shows the specificity of the effects triggered by BDNF, and may result from a differential distribution of the receptors for the two ligands in distinct synapses. In addition to the $\mathrm{KH}$ domains responsible for binding mRNAs, hnRNP $\mathrm{K}$ also possesses a $\mathrm{Kl}$ region that is responsible for the interaction with other proteins (Bomsztyk et al., 2004; Leal G., Duarte C.B. and Li K.W. unpublished observations). Since some of these binding partners may also interact with specific mRNAs (Mikula et al., 2006), it is not possible to determine whether each of the mRNAs that coimmunoprecipitate with hnRNP K bind directly or indirectly to the RNP.

BDNF was found to have a dual role in the regulation of hnRNP $\mathrm{K}$ in hippocampal neurons: it regulates the interaction of the protein with a large number of transcripts as discussed above and induces an accumulation of the RNP in dendrites following an increase in neuronal activity. The activity-dependent accumulation of hnRNP $\mathrm{K}$ in dendrites is expected to enhance the role of this RNP in synaptic regulation by BDNF, as the protein clustered in granules travel near active synapses. The effect of BDNFTrkB signaling on the distribution of hnRNP $\mathrm{K}$ may be partly mediated by activation of the Ras/ERK signaling pathway, since phosphorylation of the protein by ERK $1 / 2$ enhances its nuclear export (Habelhah et al., 2001; Mikula et al., 2006). Similarly to the effects on the dendritic distribution of hnRNP K, BDNF was shown to induce the synaptic delivery of hnRNP A2/B1, a protein belonging to the same family of RNA-binding proteins (Leal et al., 2014b). hnRNP A/B (also known as CBF-A) was also shown to transport the Arc, CaMKII $\alpha$, and the BDNF mRNAs along dendrites, and this transport in enhanced by neuronal activity (Raju et al., 2011). Activation of NMDA and AMPA receptors was found to enhance the binding of hnRNP A/B with the Arc, CaMKII $\alpha$, and the BDNF mRNAs (Raju et al., 2011), suggesting a role for the protein in the long range transport of the transcripts from the soma to the distal region of the dendrites.

In conclusion, in this work, we show that synaptic activity and BDNF regulate hnRNP $\mathrm{K}$ and hnRNP K-bound mRNAs in vitro and in vivo. The large number of transcripts showing a decreased coimmunoprecipitation with hnRNP $\mathrm{K}$ on stimulation with BDNF suggests a role for this RNP in the regulation of neuronal function in general and, in particular, in the BDNF-mediated plasticity events.

\section{References}

Atasoy D, Ertunc M, Moulder KL, Blackwell J, Chung C, Su J, Kavalali ET (2008) Spontaneous and evoked glutamate release activates two populations of NMDA receptors with limited overlap. J Neurosci 28:10151-10166. CrossRef Medline

Baj G, Pinhero V, Vaghi V, Tongiorgi E (2016) Signaling pathways controlling activity-dependent local translation of BDNF and their localization in dendritic arbors. J Cell Sci 129:2852-2864. CrossRef Medline

Benson DL (1997) Dendritic compartmentation of NMDA receptor mRNA in cultured hippocampal neurons. Neuroreport 8:823-828. Medline

Bomsztyk K, Denisenko O, Ostrowski J (2004) hnRNP K: one protein multiple processes. Bioessays 26:629-638. CrossRef Medline

Bramham CR, Southard T, Sarvey JM, Herkenham M, Brady LS (1996) Unilateral LTP triggers bilateral increases in hippocampal neurotrophin and trk receptor mRNA expression in behaving rats: evidence for interhemispheric communication. J Comp Neur 368: 371-382. CrossRef Medline

Carvalho AL, Caldeira MV, Santos SD, Duarte CB (2008) Role of the brain-derived neurotrophic factor at glutamatergic synapses. $\mathrm{Br} \mathrm{J}$ Pharmacol 153 [Suppl1]:S310-S324. CrossRef

Courtney KD, Grove M, Vandongen H, Vandongen A, LaMantia AS, Pendergast AM (2000) Localization and phosphorylation of Ablinteractor proteins, Abi-1 and Abi-2, in the developing nervous system. Mol Cell Neurosci 16:244-257. CrossRef Medline

Dziembowska M, Milek J, Janusz A, Rejmak E, Romanowska E, Gorkiewicz T, Tiron A, Bramham CR, Kaczmarek L (2012) Activitydependent local translation of matrix metalloproteinase-9. J Neurosci 32:14538-14547. CrossRef Medline

Edelmann E, Lessmann V, Brigadski T (2014) Pre- and postsynaptic twists in BDNF secretion and action in synaptic plasticity. Neuropharmacol 76 [Pt C]:610-627. CrossRef

Elvira G, Wasiak S, Blandford V, Tong XK, Serrano A, Fan X, del Rayo Sánchez-Carbente M, Servant F, Bell AW, Boismenu D, Lacaille JC, McPherson PS, DesGroseillers L, Sossin WS (2006) Characterization of an RNA granule from developing brain. Mol Cell Proteomics 5:635-651. CrossRef Medline

Fan X, Jin WY, Wang YT (2014) The NMDA receptor complex: a multifunctional machine at the glutamatergic synapse. Front Cell Neurosci 8:160. CrossRef Medline

Folci A, Mapelli L, Sassone J, Prestori F, D’Angelo E, Bassani S, Passafaro M (2014) Loss of hnRNP K impairs synaptic plasticity in hippocampal neurons. J Neurosci 34:9088-9095. CrossRef Medline

Fortin DA, Srivastava T, Dwarakanath D, Pierre P, Nygaard S, Derkach VA, Soderling TR (2012) Brain-derived neurotrophic factor activation of CaM-kinase kinase via transient receptor potential canonical channels induces the translation and synaptic incorporation of GluA1-containing calcium-permeable AMPA receptors. J Neurosci 32:8127-8137. CrossRef Medline

Gazzaley AH, Benson DL, Huntley GW, Morrison JH (1997) Differential subcellular regulation of NMDAR1 protein and mRNA in dendrites of dentate gyrus granule cells after perforant path transection. J Neurosci 17:2006-2017. Medline

Geuens T, Bouhy D, Timmerman V (2016) The hnRNP family: insights into their role in health and disease. Hum Genet 135:851-867. CrossRef Medline

Gomes JR, Costa JT, Melo CV, Felizzi F, Monteiro P, Pinto MJ, Inácio AR, Wieloch T, Almeida RD, Grãos M, Duarte CB (2012) Excitotoxicity downregulates TrkB.FL signaling and upregulates the neuroprotective truncated TrkB receptors in cultured hippocampal and striatal neurons. J Neurosci 32:4610-4622. CrossRef Medline Habelhah H, Shah K, Huang L, Ostareck-Lederer A, Burlingame AL, Shokat KM, Hentze MW, Ronai Z (2001) ERK phosphorylation drives cytoplasmic accumulation of hnRNP-K and inhibition of mRNA translation. Nat Cell Biol 3:325-330. CrossRef Medline

Hardingham GE, Fukunaga Y, Bading H (2002) Extrasynaptic NMDARs oppose synaptic NMDARs by triggering CREB shut-off and cell death pathways. Nat Neurosci 5:405-414. CrossRef Medline

Håvik B, Røkke H, Bårdsen K, Davanger S, Bramham CR (2003) Bursts of high-frequency stimulation trigger rapid delivery of pre- 
existing alpha-CaMKII mRNA to synapses: a mechanism in dendritic protein synthesis during long-term potentiation in adult awake rats. Eur J Neurosci 17:2679-2689. Medline

Huganir RL, Nicoll RA (2013) AMPARs and synaptic plasticity: the last 25 years. Neuron 80:704-717. CrossRef Medline

Hutchins EJ, Szaro BG (2013) c-Jun N-terminal kinase phosphorylation of heterogeneous nuclear ribonucleoprotein $\mathrm{K}$ regulates vertebrate axon outgrowth via a posttranscriptional mechanism. J Neurosci 33:14666-14680. CrossRef

Hutchins EJ, Belrose JL, Szaro BG (2015) Phosphorylation of heterogeneous nuclear ribonucleoprotein $\mathrm{K}$ at an extracellular signalregulated kinase phosphorylation site promotes neurofilamentmedium protein expression and axon outgrowth in Xenopus. Neurosci Lett 607:59-65. CrossRef Medline

Iwasaki T, Koretomo Y, Fukuda T, Paronetto MP, Sette C, Fukami Y, Sato K (2008) Expression, phosphorylation, and mRNA-binding of heterogeneous nuclear ribonucleoprotein $\mathrm{K}$ in Xenopus oocytes, eggs, and early embryos. Dev Growth Differ 50:23-40. CrossRef Medline

Janas J, Skowronski J, Van Aelst L (2006) Lentiviral delivery of RNAi in hippocampal neurons. Meth Enzymol 406:593-605. CrossRef Medline

Kaech S, Banker G (2006) Culturing hippocampal neurons. Nat Protoc 1:2406-2415. CrossRef Medline

Kanai Y, Dohmae N, Hirokawa N (2004) Kinesin transports RNA: isolation and characterization of an RNA-transporting granule. Neuron 43:513-525. CrossRef Medline

Kang H, Schuman EM (1996) A requirement for local protein synthesis in neurotrophin-induced hippocampal synaptic plasticity. Science 273:1402-1406. Medline

Kang H, Welcher AA, Shelton D, Schuman EM (1997) Neurotrophins and time: different roles for TrkB signaling in hippocampal longterm potentiation. Neuron 19:653-664. Medline

Kessels HW, Nabavi S, Malinow R (2013) Metabotropic NMDA receptor function is required for $\beta$-amyloid-induced synaptic depression. Proc Natl Acad Sci USA 110:4033-4038. CrossRef Medline

Kim K, Saneyoshi T, Hosokawa T, Okamoto K, Hayashi Y (2016) Interplay of enzymatic and structural functions of CaMKII in longterm potentiation. J Neurochem 139:959-972. CrossRef Medline

Kolb JE, Trettel J, Levine ES (2005) BDNF enhancement of postsynaptic NMDA receptors is blocked by ethanol. Synapse 55:52-57. CrossRef Medline

Korte M, Carroll P, Wolf E, Brem G, Thoenen H, Bonhoeffer T (1995) Hippocampal long-term potentiation is impaired in mice lacking brain-derived neurotrophic factor. Proc Natl Acad Sci USA 92: 8856-8860. Medline

Korte M, Staiger V, Griesbeck O, Thoenen H, Bonhoeffer T (1996) The involvement of brain-derived neurotrophic factor in hippocampal long-term potentiation revealed by gene targeting experiments. J Physiol Paris 90:157-164. Medline

Kosik KS (2016) Life at low copy number: how dendrites manage with so few mRNAs. Neuron 92:1168-1180. CrossRef Medline

Krichevsky AM, Kosik KS (2001) Neuronal RNA granules: a link between RNA localization and stimulation-dependent translation. Neuron 32:683-696. Medline

Laursen LS, Chan CW, Ffrench-Constant C (2011) Translation of myelin basic protein mRNA in oligodendrocytes is regulated by integrin activation and hnRNP-K. J Cell Biol 192 797-811. CrossRef Medline

Leal G, Comprido D, Duarte CB (2014a) BDNF-induced local protein synthesis and synaptic plasticity. Neuropharmacol 76 [Pt C]:639656.

Leal G, Afonso PM, Duarte CB (2014b) Neuronal activity induces synaptic delivery of hnRNP A2/B1 by a BDNF-dependent mechanism in cultured hippocampal neurons. PLoS One 9:e108175.

Liao L, Pilotte J, Xu T, Wong CC, Edelman GM, Vanderklish P, Yates JR 3rd (2007) BDNF induces widespread changes in synaptic protein content and up-regulates components of the translation machinery: an analysis using high-throughput proteomics. J Proteome Res 6:1059-1071. CrossRef

Link W, Konietzko U, Kauselmann G, Krug M, Schwanke B, Frey U, Kuhl D (1995) Somatodendritic expression of an immediate early gene is regulated by synaptic activity. Proc Natl Acad Sci USA 92:5734-5738. Medline

Liu Y, Szaro BG (2011) hnRNP K post-transcriptionally co-regulates multiple cytoskeletal genes needed for axonogenesis. Development 138:3079-3090. CrossRef Medline

Lyford GL, Yamagata K, Kaufmann WE, Barnes CA, Sanders LK, Copeland NG, Gilbert DJ, Jenkins NA, Lanahan AA, Worley PF (1995) Arc, a growth factor and activity-regulated gene, encodes a novel cytoskeleton-associated protein that is enriched in neuronal dendrites. Neuron 14:433-445. Medline

Madara JC, Levine ES (2008) Presynaptic and postsynaptic NMDA receptors mediate distinct effects of brain-derived neurotrophic factor on synaptic transmission. J Neurophysiol 100:3175-3184. CrossRef Medline

Manadas B, Santos AR, Szabadfi K, Gomes JR, Garbis SD, Fountoulakis M, Duarte CB (2009) BDNF-induced changes in the expression of the translation machinery in hippocampal neurons: protein levels and dendritic mRNA. J Proteome Res 8:4536-4552. CrossRef Medline

Martin KJ, Shpiro N, Traynor R, Elliott M, Arthur JS (2011) Comparison of the specificity of Trk inhibitors in recombinant and neuronal assays. Neuropharmacol 61:148-155. CrossRef

Messaoudi E, Kanhema T, Soulé J, Tiron A, Dagyte G, da Silva B, Bramham CR (2007) Sustained Arc/Arg3.1 synthesis controls long-term potentiation consolidation through regulation of local actin polymerization in the dentate gyrus in vivo. J Neurosci 27: 10445-10455. CrossRef Medline

Mi H, Muruganujan A, Casagrande JT, Thomas PD (2013a) Largescale gene function analysis with the PANTHER classification system. Nat Protoc 8:1551-1566. CrossRef Medline

Mikula M, Dzwonek A, Karczmarski J, Rubel T, Dadlez M, Wyrwicz LS, Bomsztyk K, Ostrowski J (2006) Landscape of the hnRNP K protein-protein interactome. Proteomics 6:2395-2406. CrossRef Medline

Minichiello L, Korte M, Wolfer D, Kühn R, Unsicker K, Cestari V, Rossi-Arnaud C, Lipp HP, Bonhoeffer T, Klein R (1999) Essential role for TrkB receptors in hippocampus-mediated learning. Neuron 24:401-414. Medline

Ostareck-Lederer A, Ostareck DH, Cans C, Neubauer G, Bomsztyk K, Superti-Furga G, Hentze MW (2002) c-Src-mediated phosphorylation of hnRNP $\mathrm{K}$ drives translational activation of specifically silenced mRNAs. Mol Cell Biol 22:4535-4543. Medline

Pal R, Agbas A, Bao X, Hui D, Leary C, Hunt J, Naniwadekar A, Michaelis ML, Kumar KN, Michaelis EK (2003) Selective dendritetargeting of mRNAs of NR1 splice variants without exon 5: identification of a cis-acting sequence and isolation of sequencebinding proteins. Brain Res 994:1-18. Medline

Panja D, Bramham CR (2014) BDNF mechanisms in late LTP formation: a synthesis and breakdown. Neuropharmacol 76 [Pt C]:664676. CrossRef Medline

Panja D, Dagyte G, Bidinosti M, Wibrand K, Kristiansen AM, Sonenberg N, Bramham CR (2009) Novel translational control in Arcdependent long term potentiation consolidation in vivo. J Biol Chem 284:31498-31511. CrossRef Medline

Panja D, Kenney JW, D'Andrea L, Zalfa F, Vedeler A, Wibrand K, Fukunaga R, Bagni C, Proud CG, Bramham CR (2014) Two-stage translational control of dentate gyrus LTP consolidation is mediated by sustained BDNF-TrkB signaling to MNK. Cell Rep 9:14301445. CrossRef Medline

Patterson SL, Grover LM, Schwartzkroin PA, Bothwell M (1992) Neurotrophin expression in rat hippocampal slices: a stimulus paradigm inducing LTP in CA1 evokes increases in BDNF and NT-3 mRNAs. Neuron 9:1081-1088. Medline

Pinto MJ, Alves PL, Martins L, Pedro JR, Ryu HR, Jeon NL, Taylor AM, Almeida RD (2016) The proteasome controls presynaptic 
differentiation through modulation of an on-site pool of polyubiquitinated conjugates. J Cell Biol 212:789-801. CrossRef Medline

Proepper C, Steinestel K, Schmeisser MJ, Heinrich J, Steinestel J, Bockmann J, Liebau S, Boeckers TM (2011) Heterogeneous nuclear ribonucleoprotein $\mathrm{k}$ interacts with $\mathrm{Abi}-1$ at postsynaptic sites and modulates dendritic spine morphology. PLoS One 6:e27045. CrossRef Medline

Raju CS, Fukuda N, López-Iglesias C, López C, Visa N, Percipalle P (2011) In neurons, activity-dependent association of dendritically transported mRNA transcripts with the transacting factor CBF-A is mediated by A2RE/RTS elements. Mol Biol Cell 22:1864-1877. CrossRef Medline

Rook MS, Lu M, Kosik KS (2000) CaMKIlalpha 3' untranslated region-directed $m R N A$ translocation in living neurons: visualization by GFP linkage. J Neurosci 20:6385-6393. Medline

Santos AR, Comprido D, Duarte CB (2010) Regulation of local translation at the synapse by BDNF. Prog Neurobiol 92:505-516. CrossRef Medline

Santos AR, Mele M, Vaz SH, Kellermayer B, Grimaldi M, ColinoOliveira M, Rombo DM, Comprido D, Sebastião AM, Duarte CB (2015) Differential role of the proteasome in the early and late phases of BDNF-induced facilitation of LTP. J Neurosci 35:33193329. CrossRef Medline

Schratt GM, Nigh EA, Chen WG, Hu L, Greenberg ME (2004) BDNF regulates the translation of a select group of mRNAs by a mammalian target of rapamycin-phosphatidylinositol 3-kinase-dependent pathway during neuronal development. J Neurosci 24:7366-7377. CrossRef Medline

Shiina N, Shinkura K, Tokunaga M (2005) A novel RNA-binding protein in neuronal RNA granules: regulatory machinery for local translation. J Neurosci 25:4420-4434. CrossRef Medline

Shioda N, Moriguchi S, Oya T, Ishii Y, Shen J, Matsushima T, Nishijo H, Sasahara M, Fukunaga K (2012) Aberrant hippocampal spine morphology and impaired memory formation in neuronal plateletderived growth factor $\beta$-receptor lacking mice. Hippocampus 22: 1371-1378. CrossRef Medline

Sirven A, Ravet E, Charneau P, Zennou V, Coulombel L, Guétard D, Pflumio F, Dubart-Kupperschmitt A (2001) Enhanced transgene expression in cord blood CD34 ${ }^{+}$-derived hematopoietic cells, including developing $T$ cells and NOD/SCID mouse repopulating cells, following transduction with modified trip lentiviral vectors. Mol Ther 3:438-448. CrossRef Medline

Steward O, Levy WB (1982) Preferential localization of polyribosomes under the base of dendritic spines in granule cells of the dentate gyrus. J Neurosci 2:284-291. Medline
Steward O, Worley PF (2001) Selective targeting of newly synthesized Arc mRNA to active synapses requires NMDA receptor activation. Neuron 30:227-240. Medline

Steward O, Wallace CS, Lyford GL, Worley PF (1998) Synaptic activation causes the mRNA for the IEG Arc to localize selectively near activated postsynaptic sites on dendrites. Neuron 21:741751. Medline

Tahir TA, Singh H, Brindle NP (2014) The RNA binding protein hnRNP-K mediates post-transcriptional regulation of uncoupling protein-2 by angiopoietin-1. Cell Signal 26:1379-1384. CrossRef Medline

Takei N, Inamura N, Kawamura M, Namba H, Hara K, Yonezawa K, Nawa H (2004) Brain-derived neurotrophic factor induces mammalian target of rapamycin-dependent local activation of translation machinery and protein synthesis in neuronal dendrites. J Neurosci 24:9760-9769. CrossRef Medline

Thomas KL, Laroche S, Errington ML, Bliss TV, Hunt SP (1994) Spatial and temporal changes in signal transduction pathways during LTP. Neuron 13:737-745. Medline

Tiruchinapalli DM, Oleynikov Y, Kelic S, Shenoy SM, Hartley A, Stanton PK, Singer RH, Bassell GJ (2003) Activity-dependent trafficking and dynamic localization of zipcode binding protein 1 and beta-actin mRNA in dendrites and spines of hippocampal neurons. J Neurosci 23:3251-3261. Medline

Tongiorgi E, Righi M, Cattaneo A (1997) Activity-dependent dendritic targeting of BDNF and TrkB mRNAs in hippocampal neurons. J Neurosci 17:9492-9505. Medline

Troca-Marín JA, Alves-Sampaio A, Tejedor FJ, Montesinos ML (2010) Local translation of dendritic RhoA revealed by an improved synaptoneurosome preparation. Mol Cell Neurosci 43:308-314. CrossRef Medline

Vanevski F, Xu B (2015) HuD interacts with Bdnf mRNA and is essential for activity-induced BDNF synthesis in dendrites. PLoS One 10:e0117264. CrossRef Medline

Yin Y, Edelman GM, Vanderklish PW (2002) The brain-derived neurotrophic factor enhances synthesis of Arc in synaptoneurosomes. Proc Natl Acad Sci USA 99:2368-2373. CrossRef Medline

Yoo Y, Wu X, Egile C, Li R, Guan JL (2006) Interaction of N-WASP with hnRNPK and its role in filopodia formation and cell spreading. J Biol Chem 281:15352-15360. CrossRef Medline

Zeitelhofer M, Karra D, Macchi P, Tolino M, Thomas S, Schwarz M, Kiebler M, Dahm R (2008) Dynamic interaction between P-bodies and transport ribonucleoprotein particles in dendrites of mature hippocampal neurons. J Neurosci 28:7555-7562. CrossRef Medline 